Veteriner Farmakoloji ve Toksikoloji Derneği Bülteni

Bulletin of Veterinary Pharmacology and Toxicology Association

e-ISSN: 2667-8381, 12 (2): 55-78, 2021

DOI: $10.38137 /$ vftd.969798

\title{
KÖK HÜCRE ÜRETIMI, İZOLASYONU VE TEDAVIDE KULLANIMI
}

\author{
Muhammet Mükerrem KAYA ${ }^{1 a}$, Hidayet TUTUN ${ }^{1 b}$ \\ ${ }^{1}$ Burdur Mehmet Akif Ersoy Üniversitesi Veteriner Fakültesi, Farmakoloji ve Toksikoloji Anabilim Dalı, Burdur
}

ORCID ${ }^{\mathrm{a}}$ : 0000-0002-7781-5342, ORCID $^{\mathrm{b}}$ : 0000-0001-9512-8637

\section{ÖZET}

Kök hücreler, çok hücreli canlıların bütün doku ve organlarını oluşturan temel hücrelerdir. Mitoz bölünme ile farklı hücre ve doku tiplerine farklılaşma ve çoğalma yeteneğine sahiplerdir. Kök hücrelerin hasarlı hücreleri değiştirme veya organları yenileme yetenekleri bazı hastalıkların tedavisinde alternatif bir tedavi seçeneği olmasını sağlamıştır. Kök hücre biyolojisinin anlaşılması ve hastalıkların tedavisinde klinik uygulamalar üzerine yoğun çalışmalar yapılmaktadır. Son yıllarda özellikle kişiye özel tedavi seçeneklerinin ön plana çıktığı çalışmalar göze çarpmaktadır. Kök hücre biyolojisinde önemli ilerlemelere rağmen, embriyonik kök hücrelerle etik tartışmalar, tümör oluşumu ve doku reddi gibi konular bunların kullanımını sınırlandırmaktadır. Kök hücre teknolojisinin gelişmesiyle yakın gelecekte farklı alanlarda kullanılabilen kök hücrelerle elde edilen doku bankalarının oluşturulması ve kişiye özel tedavi stratejisine katkı sağlaması beklenmektedir. Bu derleme, kök hücre tanımı, kökeni ve sınıflandırılması ile bu hücrelerin rejeneratif tıptaki uygulamaları üzerine odaklanır.

Anahtar Kelimeler: Kök hücre, Rejeneratif tıp, Tedavi.

\section{STEM CELL PRODUCTION, ISOLATION AND THEIR USES IN TREATMENT}

\begin{abstract}
Stem cells are the basic cells that form all tissues and organs of multicellular organisms. Stem cells have become an alternative therapy option in the treatment of various illnesses with the ability to repair damaged cells or regenerate organs. In recent years, there has been a tremendous increase in the understanding of stem cell biology and clinical applications in the treatment of diseases. Todays, stem cells have been used for therapeutic purposes alongside traditional treatment in the world. Although significant advances in stem cell biology, ethical debates regarding embryonic stem cells, tumorigenesis and rejection limit their use. The successful results in the use of stem cells have made it a new treatment strategy in diseases. It is expected that the development of stem cell technology will contribute to establishment the of tissue banks obtained from stem cells with different usage areas and to a personalized treatment strategy in the near future. This review focuses on the definition, origin and classification of stem cells and their applications in regenerative medicine.
\end{abstract}

Keywords: Stem Cell, Regenerative Medicine, Therapy.

\section{GİRİŞ}

Kök hücre çok hücreli organizmaların herhangi bir hücresine farklılaşabilen, kendini yenileme yeteneğine sahip ve aynı kök hücreden sonsuz sayıda çoğalabilen öncü hücre olarak bulunan farklılaşmamış veya kısmen farklılaşmış hücrelerdir (Zakrzewski ve ark., 2019). Kök hücrelerin bu farklılaşma yeteneği, onları dokuların rejenere edilmesi ve onarılmasında büyük bir terapötik potansiyel haline getirir (Biehl ve ark., 2009). Kök hücreler insan vücudundaki her doku ve organı oluşturan temel hücrelerdir. İnsan vücudunda sinir hücresi, kas hücresi, deri hücresi, yağ hücresi gibi yaklaşık 200 farklı özel hücre türü bulunur. Bu özel hücre türleri kök hücrelerin farklılaşması sonucu oluşur. Kök hücrelerin sahip oldukları büyüme 
faktörleri ve sitokinler ile ekstraselüler matriks ve diğer hücrelerle temasına bağlı olarak, farklılaşma yetenekleri değişiklik gösterir. Bazı kök hücreler yalnızca belirli hücrelere farklılaşma yeteneğine sahipken, bazıları ise birçok hücre türüne farklılaşma yeteneğine sahiptir (Clause ve ark., 2010; Devkate ve ark., 2019). Kök hücreler sahip oldukları kendini yenileme ve potens adı verilen özellikleri ile diğer hücrelerden ayrilırlar. Potens terimi; hücrelerin, çeşitli türdeki hücrelere farklılaşması olarak tanımlanır (Kalra ve ark., 2014; Singh ve ark., 2016). Kök hücre ilgili çalışmalar 1868 yılında Alman biyolog Ernst Haeckel tarafindan yapılmaya başlanmıştır. Haeckel yaptığı çalışmalarda tüm çok hücreli organizmaların tek bir ata hücreden geldiğini tanımlamak için almanca kök hücre anlamına gelen "Stammzelle" terimini kullanmıştır. Kök hücrelerin özelleşmiş hücrelere farklılaşabilme yeteneğinin ortaya konması ise 19. yüzyılın sonlarında August Weismann tarafından ortaya atılmıştır. Theodor Boveri ve Valentin Häcker, Wismann'ın teorisini destekleyerek, genetik materyalin bozulmadan gelecek nesillere aktarıldığını ortaya koymuşlardır. Boveri ve Häcker yaptıkları çalışmalarda ilk kez kök hücre terimini kullanmışlardır. Kök hücrelerin temel özellikleri ile ilgili ilk çalışmalar 1960'lı yıllarda Ernest McCulloch ve James Till tarafindan yapılmıştır. Amerikalı biyolog James Thomson 1998 yılında embriyonik kök hücreleri izole etmeyi başarmıştır (Ramalho-Santos ve Willenbring, 2007). Yapılan bu çalışmalar 1şığında kök hücrelerin yeni bir teröpatik potansiyeli olduğu ortaya konmuştur. $\mathrm{Bu}$ derlemede kök hücrelerin farklılaşması, sinıflandırması, izolasyonu ve tedavide kullanımı hakkında bilgi verilmesi amaçlanmıştır.

\section{KÖK HÜCRELERİN FARKLILAȘMASI}

Kök hücreler organizmada bulunan farklılaşmamış hücrelerdir ve herhangi bir hücre tipine dönüşebilirler. Kök hücreler hem embriyoda hem de yetişkin bireylerde bulunurlar. Kök hücrelerin farklılaşmaları çeşitli şekillerde meydana gelir (Zakrzewski ve ark., 2019). Sahip oldukları farklılaşma yeteneklerine göre totipotent, pluripotent, multipotent veya unipotent şeklinde sınıflandırılırlar (Rajabzadeh ve ark., 2019).

\section{Totipotent kök hücreler}

Totipotent tanımı, organizmada tek bir hücrenin ekstraembriyonik dokular da dahil olmak üzere organizmada bulunan hücrelere farklılaşması olarak tanımlanır. Totipotent kök hücreler, vücutta bulunan tüm hücrelere farklılaşabilme yeteneğindeki kök hücrelerdir. Bu özelliğe sahip olduğu bilinen tek kök hücre tipi fertilize yumurta hücresi olan zigot hücresidir. Zigot hücresi sahip olduğu özellikle organizmadaki tüm özel hücre tiplerinin oluşumu ve fötal gelişim için gerekli olan plasental yapıların oluşumunu sağlar (Mitalipov ve Wolf, 2009; Oyar ve ark., 2015).

\section{Pluripotent kök hücreler}

Pluripotent kök hücreler endoderm, mezoderm ve ektodermden oluşan embriyonik yaprakların herhangi birine farklılaşma yeteneğine sahip kök hücreler olarak ifade edilmektedir. Bu kök hücreler totipotent kök hücrelerden oluşan hücrelerdir. Ancak totipotent hücreler gibi ekstraembriyonik yapıların oluşumuna katılmazlar. Pluripotent kök hücreler fötal veya yetişkin herhangi bir hücre tipine (200 farklı tiptedeki hücreye) farklılaşabilir. İmplantasyon sonrasında 
embriyonun blastosist katmanından izole edilebilirler (Mitalipov ve Wolf, 2009; Kumar ve ark., 2010; Girlovanu ve ark., 2015).

Pluripotent olmayan kök hücrelere embriyonik evrede bazı transkripsiyon faktörlerinin eklenmesi ile oluşturulan kök hücrelere indüklenmiş pluripotent kök hücreler (iPSC) denir. iPSC'ler implantasyondan sonra epiblast katmanından izole edilirler. Bu hücreler doğrudan somatik hücrelerden gen ekspresyonu ve farklılaşmanın tersine çevrilmesi sonucu elde edilen hücrelerdir. iPSC'ler tipik olarak belirli bir hücre tipine potens ile ilişkili germ kümelerinin veya Oct4 (Octamer-binding transcription factor 4), Sox2 (Sex determining region Y-box 2), cMyc ve Klf4 (Kruppel-like factor 4) gibi yeniden programlama ile ilişkili transkripsiyon faktörlerinin aktarılmasıyla elde edilirler. $\mathrm{Bu}$ hücrelerin üretilmesi uzun ve verimsiz süreçler içerir. Fare hücreleri için 1-2 hafta, insan hücreleri için ise 3-4 hafta sürer ve verimlilik ise yaklaşık $\% 0,1$ 'dir. Yapılan çalışmalarla yeniden programlama faktörlerinin eklenmesi iPSC üretiminde verimin artmasını sağlamıştır (Ye ve ark., 2013; Guo ve ark., 2015).

\section{Multipotent kök hücreler}

Multipotent kök hücrelerin farklılaşma yetenekleri pluripotent kök hücrelerinden daha sinırlıdır ve sadece belirli hücre soylarındaki ayrı hücre tiplerine farklılaşma yeteneğine sahiptirler. Multipotent kök hücrelerin çok sayıda hücre tipine dönüşmesi farklılaşma kabiliyetlerini kaybetmelerine neden olur ve sadece küçük bir kısmı bu özelliklerini korur. Örneğin; beyinde bulunan multipotent kök hücreler kan hücrelerine farklılaşabilen farklı nöral hücreler ve glia hücreleri veya hematopoietik kök hücreler üretebilirler; ancak sinir hücrelerine farklılaşma yeteneğine sahip değildirler. Multipotent kök hücreler sınırlı farklılaşma yeteneklerinden dolayı erişkin kök hücre olarak kabul edilirler ve gelişim, doku onarımı ve savunma mekanizmalarında önemli anahtar görevlere sahiptirler. Yapılan çalışmalarda nöral ve kardiyak bozukluklar gibi çok sayıda bozukluğun tedavisi için multipotent kök hücre uygulamasının potansiyel bir teröpatik etkisi olduğu belirtilmiştir (Blau ve ark., 2001; Girlovanu ve ark., 2015; Oyar, 2015; Zakrzewski ve ark., 2019).

\section{Unipotent kök hücreler}

Tek hücre anlamına gelen unipotent hücreler bir kök hücrenin yalnızca bir hücre ve doku tipine farklılaşma yeteneğine sahip olduğunu gösterir (Bernemann ve ark., 2011). Kas hücreleri unipotent hücrelere örnek olarak verilebilir. Yetişkin dokularda diğer kök hücrelere kıyasla farklılaşma potansiyeli en düşük olan hücrelerdir. $\mathrm{Bu}$ tip hücrelerin kendilerini yenileme yeteneği yoktur. Sınırlı farklılaşma yeteneklerine rağmen çeşitli hastalıkların tedavisinde bir potansiyel olarak görülürler (Rajabzadeh ve ark., 2019).

\section{KÖK HÜCRELERİN SINIFLANDIRILMASI}

Kök hücreler farklılaşma kapasitelerine göre ya da elde edildikleri kaynağa göre sınıflandırılırlar. Kök hücreler elde edildikleri kaynağa göre embriyonik ve yetişkin kök hücreler olmak üzere ikiye ayrılırlar. Yetişkin kök hücreler fötal kök hücrelerden, kadavradan, göbek kordonundan, plasentadan, kemik iliğinden, yağ dokudan, birçok organda bulunan somatik kök hücrelerden elde edilebilir (Barky ve ark., 2017; Çerçi ve Erdost, 2019).

\section{Embriyonik kök hücreler}

Embriyonik kök hücreler memeli blastosistinin iç hücre kitlesinden elde edilebilen, pluripotent yapıda ve kendi kendini yenileme yeteneğine sahip 
hücrelerdir. Endoderm, mezoderm ve ektoderm gibi embriyonik yapraklara ve her türlü somatik hücreye farklılaşabilirler. $\mathrm{Bu}$ özellikleri sebebiyle doku rejenerasyonunda kullanılırlar. İmplantasyon gerçekleşmeden önce uterusta bulunan gelişim aşamasındaki embriyolardan elde edilirler. Embriyo gelişiminin ilk döneminden 4-5 günlük bir süre sonra kültür ortamına alınırlar. Kültür ortamında farklılaşmamış şekilde dondurularak saklanabilir ve istenen herhangi bir hücre hattına farklılaşmaları için uyarılabilirler (Barky ve ark., 2017; Rajpoot ve Tewari, 2018).

\section{Yetişkin kök hücreler}

Yetişkin dokularda bulunan kök hücreler organizmada sınırlı ölçüde kendini yenileme ve farklılaşma yeteneğine sahip hareketsiz hücrelerdir. Yetişkin dokularda çok sayıda kısmen farklılaşmış hücre olan öncü (progenitör) hücre türleri olduğu tespit edilmiştir, bu da dokuların kendi kök hücrelerine sahip olduğunu gösterir. $\mathrm{Bu}$ hücreler organizmada fizyolojik yıkımlanmaların veya patolojik süreçler sonucu oluşan hasarların giderilmesinden sorumludurlar (Chagastelles ve Nardi, 2011; Barky ve ark., 2017).

Yetişkin kök hücreler multipotent ve unipotent yapıdadır ve belirli tip hücrelere farklılaşabilirler. İnsan vücudunda en fazla yetişkin kök hücre kemik iliğinde bulunur. Bununla birlikte göbek kordunu kanı, periferik kan, amniyotik sıv1, merkezi sinir sistemi, deri epidermisi, sindirim kanalı, iskelet kası, kornea, retina, pankreas, karaciğer, kalp, yağ dokusu ve akciğer gibi birçok doku ve organdan izole edilebilirler (Oyar, 2015).

Organizmada bulunan birçok dokuda yerleşik şekilde bulunan yetişkin kök hücreler onarım, hastalık veya yaralanma sonucu kaybedilen hücrelerin yerini alacak yeni hücreler üretirler. Bu dokularda bulunan yetişkin kök hücreler kaynak dokularının dışında farklı hücre tiplerine farklılaşma yeteneğine sahiptirler (Passier ve Mummery, 2003).

\section{Hematopoetik kök hücreler}

Hematopoetik kök hücreler (HSC) kendi kendini yenileme potansiyeline sahip ve tüm hematopoetik hücrelere farklılaşarak diğer kan hücrelerinin oluşumunu sağlayan hücrelerdir. $\mathrm{Bu}$ sürece hematopoez adı verilir. Hematolojik bozuklukların tedavisinde ve kötü huylu hastalıklarda tam iyileşme sağlayabilmek için yüksek dozda kullanılırlar (Barky ve ark., 2017).

Omurgalılarda bu sürecin büyük bir kısmı kemik iliğinde meydana gelir. Hematopoetik kök hücreler miyeloid ve lenfoid adı verilen farklı kan hücrelerinin üretilmesini sağlarlar. Miyeloid ve lenfoid hücrelerin her ikisi de dendritik hücre oluşumunda rol oynar. Miyeloid hücreler arasında monositler, makrofajlar, nötrofiller, bazofiller, eozinofiller, eritrositler ve megakaryositler ile trombositler bulunur. Lenfoid hücreler arasında $\mathrm{T}$ hücreleri, B hücreleri, doğal öldürücü hücreler bulunur. Hematopoetik kök hücreler miyeloid dokuda 1:10.000 oranında hücrenin oluşumunu sağlar. HSC nakilleri, kanserlerin ve diğer bağışıklık sistemi bozukluklarının tedavisinde kullanılırlar (Till ve McCulloch, 1961; Ng ve ark., 2009; Birbrair ve Frenette, 2016).

\section{Mezenkimal kök hücreler}

Mezenkimal kök hücreler (MSC) insan ve hayvanlardan izole edilebilen yetişkin kök hücrelerdir. İnsanlardan izole edilen MSC'ler (hMSC) osteosit, adiposit ve kondrosit gibi mezodermal kaynaklı hücre tiplerine farklılaşma yeteneğine sahip multipotent yapıdaki kök hücrelerdir. hMSC'ler ilk kez kemik iliğinde tespit edilmiştir ve yapılan 
çalışmalarda yağ dokusu, amniyotik sıvı, endometriyum, diş dokusu, göbek kordonu ve göbek kordonunu çevreleyen yapı olan Wharton peltesi MSC'leri barındıran potansiyel yapılar olarak bildirilmiştir (Ullah ve ark., 2015). hMSC için en yaygın olarak kullanılan kaynak kemik iliği ve adipoz dokudur. Kültür ortamında hızlı çoğalma yeteneğine sahip olan MSC'lerin gelişmesiyle daha önce diğer hücrelerde bulunmayan hücre içi farklılaşma potansiyellerine sahiptirler ve ayrıca fazla miktarda yararlı büyüme faktörü ve sitokin üretme yetenekleri bulunur (Pittenger ve ark., 2019).

MSC'ler belirli hücre sinyalleri sonucu çok sayıda özel hücre tipine farklılaşma yeteneğine sahiptirler. Mezodermal (osteoblastlar, kondrositler, adipositler, miyositler, kardiyomisitler), ektodermal (nöronal hücreler) ve endodermal (hepatik, pankreatik ve solunum epiteli gibi) hücre tiplerine farklılaşabilirler (Song ve Tuan, 2004).

MSC'lerin önemli özelliklerinden biri, immünmodulatör etkiye sahip olmalarıdır. In vitro olarak elde edilen MSC'ler doğal ve kazanılmış bağışıklık süreçlerinde yer alan efektör hücrelerin işlevlerini düzenleme yeteneğine sahiptirler. Mononükleer hücre proliferasyonunu inhibe ederek doğal ve aktif nötrofillerin apoptozunu bloke eder ve vasküler endotel hücrelere bağlanan nötrofillerin sayısını azaltır ayrıca bölgeye göç etmelerini sınırlayarak immünmodülatör etki gösterirler. Aynı zamanda aktive MSC'ler tarafindan sentezlenen sitokinler, nötrofil kemotaksisini ve fagositik etkiye sahip makrofajların bölgede toplanmasını ve uyarılmasında görev alan proinflamatuar kemokinlerin salgılanmasını uyarıcı etkisi bulunur (Andrzejewska ve ark., 2019).

Makrofajlar inflamasyon bölgesinde sitokin üretiminden sorumlu ana hücrelerdir ve bu sebeple immünmodülasyonun sağlanması için odak noktasını oluştururlar. Yapılan çalışmalarda MSC'lerin makrofajlar tarafindan üretilen TNF- $\alpha$ (Tümör nekroz faktörü alfa), IL-6 (İnterlökin-6) ve IFN-Y (Interferon gamma) gibi proinflamatuar sitokinlerin üretimini inhibe ettiği belirtilmiştir. $\mathrm{Bu}$ sayede bağışıklık hücrelerinin aktivasyonu ve lokal olarak inflamasyon sürecini kontrol altına alınarak doku hasarı azaltılır. MSC'ler ayrıca inflamasyon bölgelerinin temizlenmesinde önemli rol oynayan fagositik aktiviteye sahip apoptotik hücrelerin gelişimine katkı sağlarlar (Semedo ve ark., 2011).

MSC’ler B lenfositlerinin gelişimi ve farklılaşması sırasında hücre bölünme fazı olan G0 ve G1 aşamalarında döngünün durdurulmasının indüklenmesini sağlayabilir aynı zamanda immüngloblin üretimi için gerekli olan Blimp-1 adı verilen çözünür moleküllerin salınmasıyla, B lenfositlerin farklılaşması ve aktivasyonu modüle edebilirler (Cao ve ark., 2015; Le Blanc ve ark., 2015).

\section{Epidermal kök hücreler}

Deri organizmanın bütünlüğünü sağlayan, patojenler için ilk bariyer görevi gören vücudun en büyük organıdır. Dehidrasyonun önlenmesi, vücut ısısının düzenlenmesi, dokunma, basınç, 1sı ve ağrı duyularının sağlanması gibi önemli işlevlere sahiptir. Aynı zamanda doğal ve kazanılmış bağışıklık sistemlerini yapısında barındırır. Deri üç ana katmandan oluşmaktadır. Bunlar epidermis, dermis ve hipodermistir. Derinin en dış katmanını oluşturan epidermiste kıl folikülleri, yağ bezleri ve ter bezleri gibi çeşitli oluşumlar bulunur. Memeli epidermisinde kendini yenileme yeteneğine sahip keratinositten oluşan epidermal kök hücreler k1l folikülü ve yağ bezlerinin oluşturduğu yapı olan pilosebase unit etrafında yer alırlar. Sabit lokalizasyon gösterirler ve yüksek proliferasyon yeteneğine sahiptirler. Cildin homeostazını korur, yara iyileşmesini sağlar ve 
neoplazma oluşumunun önüne geçerler (Barky ve ark., 2017; Yang ve ark., 2019).

Epidermal kök hücreler sahip oldukları yüzey belirteçleri ile diğer hücrelerden ayrilırlar. Yüzeylerinde yüksek düzeyde CD34, CD200, $\beta$ integrin ve $\alpha$ integrin ekspresyonu gösterirler, ayrıca düşük düzeyde CD45 ve CD71 ekspresyonu da gösterirler (Cotsarelis, 2006; Köse, 2015).

Epidermal hücrelerin bazal tabakası tabakalı skuamöz epitelyumu şekillendirmek amacıyla en diş tabaka olan stratum korneum tabakasına kadar çoğalır ve terminal farklılaşma için cilt yüzeyine doğru farklılaşmaya başlar. Epidermal kök hücreler niş adı verilen kök hücre popülasyonunu çevresel hasara ve pigmentasyona karşı koruyan bölgeden çıkıp hücrelerin ara ürünlerini oluşturarak en dış tabakaya hareket ederler. Epidermal kök hücrelerin homeostazı, farklılaşması ve proliferasyonu için farklı sinyal yolakları olduğu bildirilmiştir. Notch, Wnt/ $\beta$-katenin, c-myc ve p63 yolakları epidermal kök hücre çekirdek ağını oluştururlar. Notch sinyal yolağı, Notch'un TNF- $\alpha$ dönüştürücü enzim (TACE) ve p-sekretaz tarafından NICD'ye (Notch hücre içi alan) bölünmesi ile aktive edilir. Sonuç olarak NICD, CBF1/CSL transkripsiyon faktörünü bir gen baskılayıcıdan bir gen aktivatörüne dönüştürür, böylece Hes ve Hey ailesi gibi aşağı yönde hedef genlerin transkripsiyonunu başlatır (Shen ve ark., 2013).

\section{Hepatik kök hücreler}

Karaciğer çok sayıda işlevi yerine getiren karmaşık yapıda bir organdır, bu nedenle birden çok hasar ve işlev bozukluğuna karşı hassastır. Karaciğer hasarın tipine veya boyutuna göre farklı rejenerasyon kapasitesine sahiptir. Olgun karaciğer hücreleri hasarlı dokuları yenilemek için çoğalır ve iyileşme için parankimal fonksiyon gösterirler (Verhulst ve ark., 2015).

Karaciğer anatomik ve çeşitli işlevler bakımından insan vücudundaki en fonksiyonel organlardan biridir. Ekzokrin ve endokrin bez olarak işlev görmektedir. Sindirim sisteminin düzenlenmesi, aynı zamanda vücudun savunması ve toksik maddelerin yok edilmesi için birçok işlevi yerine getirir. Hepatositler, biliyer epitel hücreleri (kolanjiyositler), Kupffer'in yıldız hücreleri ve karaciğer sinüzoidal endotel hücreleri dahil olmak üzere farklı hücre tiplerinden oluşur. Yüksek rejenerasyon kabiliyetine sahip olan hepatositler çeşitli yaralanmalar sonrasında dokunun hasarlı alanlarının onarımını sağlarlar (Messina ve ark., 2020).

Karaciğer dokularında oluşan hasarın giderilmesi olgun hepatositlerin çoğalması ve sinüzoidal hücrelerin desteklenmesi ile gerçekleşir. Deney hayvanlarında yapılan çeşitli çalışmalar hepatositlerin hasarlı karaciğer dokusunda mitoz bölünmeye uğradığını ve işlev kaybı olmadan en az 69 kez bölünebileceğini göstermiştir. $\mathrm{Bu}$ nedenle hepatositerin hematopoietik kök hücrelere benzer şekilde büyüme potansiyeline sahip olduğunu gösterilmiştir (Overturf ve ark., 1997). Hepatositlerin rejenerasyonun başlamasında Nükleer Faktör KappaB, STAT3, AP-1 ve C/EBP- $\beta$ gibi transkripsyon faktörlerinin rol oynadığı belirtilmiştir (Kountouras ve ark., 2001). Hepatositlerin yaşam süresi boyunca geniş parankimal hücre sayısını muhafaza etme kapasitesi gibi özellikleri hepatositlerin kök hücre olarak sınıflandırılmasını sağlamıştır (Zhang ve ark., 2003).

\section{Pankreatik kök hücreler}

Pankreas ekzokrin ve endokrin olmak üzere iki tip 
dokudan oluşur. Ekzokrin doku genel olarak sindirim enzimleri ve bikarbonat salgılayan asiner hücrelerden oluşur. Endokrin doku ise glukagon, insülin, somatostatin, pankreas polipeptidi veya grelin salgilayan hücrelerden oluşur. $\mathrm{Bu}$ hormonlar metabolik sinyallere yanıt olarak doğrudan sistemik dolaşıma salınırlar (Ku ve ark., 2008).

Pankreatik kök hücrelerin varlığı üzerinde tartışmalar bulunmaktadır. Ortak düşünce pankreas hasarını takiben $\beta$ hücre replikasyonu ve pankreas kanallarının yakınında ve içinde bulunan progenitör hücrelerin farklılaşması ile gerçekleştiği yönündedir. Yapılan çalışmalar sonucunda fare pankreas kök hücrelerinin güçlü şekilde kendini yenileyebildiği bildirilmiştir. $\mathrm{Bu}$ hücrelerin glukagon, insülin ve somatostatin üreten hücrelere farklılaştığı bildirilmiştir. Sonuç olarak pankreas kanallarının içinde ve yakınında bulunan hücrelerin multipotent karakterde kök hücreler olabileceği belirtilmiştir (Noguchi, 2010).

\section{Gastrointestinal kök hücreler}

Gastrointestinal sistemde yer alan epitel hücrelerin döngüsü fizyolojik şartlar altında 2-7 günlük bir süreç sonunda meydana gelir. Bu süreç gastrointestinal kanalda bulunan epitel hücrelerini ve mide bezleriyle tüm bağırsak kript hücrelerini oluşturabilen multipotent kök hücreler tarafından sağlanır. Gastrointestinal kök hücrelerin mide bezlerinde ve bağırsak kriptlerinde belirli nişlerde yer aldığı bildirilmiştir. $\mathrm{Bu}$ hücreler progenitör hücreler aracılığıyla bağırsakta yer alan tüm hücre tiplerine farklılaşabilirler (Brittan ve Wright, 2002).

Gastrointestinal kök hücreler mide epitelyal kök hücreler ve bağırsak kök hücreler olmak üzere iki sınıftan oluşurlar. Bağırsak kök hücrelerinde Wnt sinyali bağırsak kript hücrelerinin çoğalması için gereklidir ve bu sinyal yolunun hedef geni olan lösin açısından zengin G-protein bağlı reseptör 5'in (LGR5) kript tabanındaki hücrelerde eksprese edildiği tespit eldilmiştir. LGR5 pozitif hücreler kript tabanında yer alması, pluripotent ve kendi kendiğini yenileme yeteneğine sahip olduğu için LGR5'in bağırsak kök hücreleri için iyi bir belirteç olduğu sonucuna varmışlardır. Bununla birlikte bu hücrelerin aktiveleri Wnt, Notch, BMP, PI3K gibi sinyal yolakları tarafından düzenlenmektedir. Bu yolaklarda meydana gelebilecek kusurlar kanser gelişimine sebep olabilir. Mide epitelyal kök hücrelerin midede antral-pilorik segment bölgesinde skuamokolumnar bileşke yakınındaki korpus alanında bulunduğu tespit edilmiştir. Yüzeylerinde bağırsak kök hücrelerinde olduğu gibi LGR5'i eksprese ettikleri belirlenmiştir. Ayrıca mide epitel hücrelerinin kendini yenileme, farklılaşma, homeostazisin sağlanması ve tümör oluşumunun önlenmesinde Notch sinyal yolağının kullanıldığı bildirilmiştir (Brabletz ve ark., 2009; Pirvulet, 2015).

\section{Nöral kök hücreler}

Nöral kök hücreler (NSC) sinir sisteminde yer alan kök hücrelerdir. Gelişim sırasında sinir sisteminin oluşumunu sağlarlar. Embriyonik gelişim aşamalarında memelilerin sinir sisteminde nöronlarını ve glia'larını oluşturan radyal glial progenitör hücreleri oluştururlar ve multipotent hücrelerdir. Gelişim tamamlandıktan sonra yetişkinlerde az sayıda NSC kalır ve genellikle hareketsiz şekilde bulunurlar. Gelişim aşamasında memelilerde merkezi sinir sisteminin gelişimi nöral tüpü kaplayan NSC'ler ile oluşur. Merkezi sinir sistemindeki üç ana hücre tipi olan nöronlar, astrositler ve oligodendrositler zamanla sirasiyla NSC'lerden farklılaşırlar (Clarke ve ark., 2000; Zhao ve Moore, 2018). 
Epidermal büyüme faktörü (EGF) ve fibroblast büyüme faktörü-2 (FGF-2) in vitro ve in vivo koşullarda nöral kök hücrelerin ve progenitör hücrelerin proliferasyonunu ve oranını etkilerler. (Taupin ve ark., 2000).

\section{KÖK HÜCRE IZOLASYONU}

Çeşitli dokularda, kemik iliğinde ve kanda bulunan kök hücrelerin doku ve organlarda oluşan hasarların rejenerasyonunu sağladığı son yıllarda yapılan birçok çalışmada ortaya konmuştur. Yapılan yoğun çalışmalar ile basitleştirilmiş, verimli, kullanıma uygun, işlevsel şekilde kullanılabilen ve birçok doku türüne uygulanabilen kök hücre izolasyon teknikleri geliştirilmiştir. $\mathrm{Bu}$ teknikler geleneksel ayırma yöntemleri ve yeni yöntemler olarak ikiye ayrılırlar (Zhu ve Murthy, 2013).

\section{Geleneksel kök hücre izolasyon yöntemleri}

Kök hücre izolasyonu genel olarak iki farklı parametreye göre yapılır. Bunlar boyut ve yoğunluğa dayalı olan fiziksel teknikler ve kimyasal, elektriksel ve manyetik özelliklere bağlı afiniteye dayalı tekniklerdir (Tablo 1). Fiziksel teknikler kök hücrelerin aynı dokudaki diğer hücrelere göre farklı boyut ve yoğunluğa sahip olmasına dayanır (Radisic ve ark., 2006).

Tablo 1. Geleneksel Kök Hücre İzolasyon Yöntemleri (Zhu ve Murthy, 2013).

\begin{tabular}{|c|c|c|c|}
\hline Yöntem & Avantaj & Dezavantaj & Örnekler \\
\hline $\begin{array}{l}\text { Yoğunluk gradyan } \\
\text { santrifüjü }\end{array}$ & $\begin{array}{l}\text { Büyük işlem hacmi, } \\
\text { Kolay ölçeklendirme }\end{array}$ & $\begin{array}{l}\text { Düşük saflık, daha } \\
\text { fazla heterojenlik }\end{array}$ & Ficoll-paque; Percoll \\
\hline $\begin{array}{l}\text { Yoğunluk gradyan } \\
\text { santrifüjü -negatif } \\
\text { seçim }\end{array}$ & $\begin{array}{l}\text { Büyük işlem hacmi, } \\
\text { kolay ölçeklendirme, } \\
\text { yüksek saflık }\end{array}$ & $\begin{array}{l}\text { Sadece tam kanda } \\
\text { uygulanır }\end{array}$ & $\begin{array}{l}\text { RosetteSep (Kök Hücre } \\
\text { Teknolojisi) }\end{array}$ \\
\hline Ön kaplama & $\begin{array}{l}\text { Büyük işlem hacmi, } \\
\text { kolay ölçeklendirme }\end{array}$ & $\begin{array}{l}\text { Düşük saflık, daha } \\
\text { fazla heterojenlik }\end{array}$ & $\begin{array}{l}\text { İnsan embriyonik kök } \\
\text { hücreleri; insan yağ } \\
\text { hücresinden türetilmiş } \\
\text { kök hücreler }\end{array}$ \\
\hline $\begin{array}{l}\text { Koşullu } \\
\text { genişletme ortamı }\end{array}$ & $\begin{array}{l}\text { Büyük işlem hacmi, } \\
\text { Kolay ölçeklendirme }\end{array}$ & $\begin{array}{l}\text { Düşük saflık, daha } \\
\text { fazla heterojenlik }\end{array}$ & $\begin{array}{l}\text { Kemik iliğinden insan } \\
\text { mezenkimal kök } \\
\text { hücreleri }\end{array}$ \\
\hline $\begin{array}{l}\text { Dielektroforez } \\
\text { (DEP) }\end{array}$ & $\begin{array}{l}\text { Kök hücreler üzerinde } \\
\text { etiketleme gerek } \\
\text { duyulmaz, hücreleri } \\
\text { canlılığa göre sıralanır }\end{array}$ & $\begin{array}{l}\text { Çapraz reaktivite } \\
\text { düşük saflığa neden } \\
\text { olur }\end{array}$ & $\begin{array}{l}\text { Canlı yağ hücresi } \\
\text { kaynaklı kök hücreler }\end{array}$ \\
\hline $\begin{array}{l}\text { Alan akış } \\
\text { fraksiyonlama } \\
(\mathrm{FFF})\end{array}$ & $\begin{array}{l}\text { Kök hücrelerin pozitif } \\
\text { veya negatif yükle } \\
\text { etiketlenmesi gerekmez }\end{array}$ & $\begin{array}{l}\text { Kök hücreleri } \\
\text { yalnızca boyut ve } \\
\text { yoğunluk } \\
\text { farklıliklarına göre } \\
\text { ayırabilir }\end{array}$ & $\begin{array}{l}\text { Fetal membrandan insan } \\
\text { mezenkimal kök } \\
\text { hücreleri }\end{array}$ \\
\hline $\begin{array}{l}\text { Ak1Ş sitometrisi } \\
\text { (FACS) }\end{array}$ & $\begin{array}{l}\text { Güçlü, } \\
\text { hassasiyet, } \\
\text { çözünürlük }\end{array}$ & $\begin{array}{l}\text { Operasyon için iyi } \\
\text { eğitimli personel } \\
\text { gerektirir, pahalı, } \\
\text { büyük ölçekli işlemler } \\
\text { için değil, özel bir } \\
\text { aparat gerektirir }\end{array}$ & $\begin{array}{l}\text { İnsan Embriyonik Kök } \\
\text { Hücre Türevli Nöral } \\
\text { Hücre Popülasyonları, } \\
\text { insan hematopoietik kök } \\
\text { ve progenitör hücreler }\end{array}$ \\
\hline $\begin{array}{l}\text { Manyetik Aktif } \\
\text { Hücre Siralama } \\
\text { (MACS) }\end{array}$ & FACS'den daha basit & $\begin{array}{l}\text { Hedef kök hücreler } \\
\text { manyetik parçacıklar } \\
\text { içerir }\end{array}$ & $\begin{array}{l}\text { Kolonsuz EasySep (Kök } \\
\text { Hücre Teknolojisi); } \\
\text { MACS (Miltenyi) }\end{array}$ \\
\hline
\end{tabular}




\section{Yoğunluk gradyan santrifüjü}

Yoğunluk gradyan santrifüjü pahalı olmayan bir hücre ayırma tekniğidir. Bununla birlikte sınırlı özgüllük, düşük saflık ve düşük verim gösterir. Sıklıkla kullanılan bir laboratuvar tekniği olmasına rağmen uzmanlaşması zor, yavaş ve zahmetli bir süreç içerir. Yoğunluk gradyan ortamının kullanması yaklaşık 30 dakika boyunca aralıksız süren santrifüjleme ardından uygun hücre katmanını dikkatlice hasat edip yıkanmalarını gerektiren bir süreçtir. Bu metot heterojen bir örnek içinde bulunan hücrelerin (Örn; tam kan) sahip oldukları değişken yoğunluklarına dayanmaktadır. Santrifüj işleminden önce numuneye yoğunluk gradyan ortamı eklenir (Örn; Ficoll-paque; Percoll). Santrifüj işlemi sırasında her hücre tipi hücrelerin ve ortamın yoğunluğuna eşit olduğu gradyan bölgesinde yer alır ve bu sayede kök hücrelerin diğer hücrelerden ayrılması sağlanır (Majekodunmi ve ark., 2015).

\section{Ön kaplama}

Ön kaplama tekniği farklı hücre tiplerini ayırmak için uzun yıllardır yaygın şekilde kullanılan bir tekniktir. Bu teknik hücrelerin jelatin kaplı kültür yüzeyine farklı yapışma özelliklerine dayanır. Özellikle kas kök hücrelerinin ayrılmasında kullanılır. Ayrışmış kas dokusunda bulunan kas hücrelerinin kültür plakasına yapışması fibroblast ve epitel hücrelerine göre daha uzun sürmektedir. Hücrelerin kültür plakasına eklenmesinden yaklaşık 60 dakika sonra süpernatant toplanarak oldukça saflaştırılmış kök hücre popülasyonu elde edilebilir. $\mathrm{Bu}$ yöntemle \%90 oranında verim sağlanabileceği bildirilmiştir. Fare miyeloblastlarında integrin $\alpha 7$, MyoD ve desmin gibi miyojenik belirteçlerin ekspresyonuna dayalı olarak yapılan ön kaplama ile \%98'e kadar saflık elde edilmiştir (Park ve ark., 2006; Choi ve ark., 2021).

\section{Koşullu genişletme ortamı}

Bu metot mezenkimal kök hücrelerin izolasyonu için kullanılır. Bu hücreler kültür ortamında fibroblast hücrelerine benzer şekilde tutunabilirler ancak kendini yenileme ve farklılaşma kapasiteleri sınırlıdır. Kemik iliğinden elde edilen mezenkimal kök hücrelerin telomer uzunluğunun kısalması ve uğradığı morfolojik değişikliklerle kültür ortamında hızlı şekilde yaşlanabileceği belirtilmiştir. Hastalarda mezenkimal kök hücrelerin kullanımı önemli yer tutmaktadır. Bu sebeple bu hücrelerin karakterlerinin korunması tedavide önemlidir. Bunun için kültür ortamında hücrelerin korunmasını sağlayan farklı genişletme ortamları oluşturulmuştur. Bunların en sık kullanılanları fetal buzağı serumu (FCS) ve L-glutamin içeren DMEM (Dulbecco's Modified Eagle's medium) ortamıdır. Bunların yanında temel fibroblast büyüme faktörü (b-FGF) gibi büyüme faktörlerini de içeren büyüme ortamı da kullanılır. Bunun için en yaygın kullanılan medium, \%60 düşük glikozlu DMEM, \%40 MCDB201, $1 \times$ insülin transferin selenyum, $1 \times$ linoleik asit sığır serum albümini (BSA), $10^{-9} \mathrm{M}$ deksametazon ve $10^{-4} \mathrm{M}$ askorbik asit, 2-10 ng/mL EGF (Epidermal Growth Factor) ve 10 ng/mL PDGF-BB (Recombinant Human Platelet Derived Growth Factor-BB) ile desteklenmiş fosfat içeren, Catherine Verfaillie tarafından oluşturulan genişletme ortamıdır. Mezenkimal kök hücrelerin kültür ortamında genişlemesiyle ilgili farklı veriler bildirilmiştir. Bazı araştırmacılar 19-21 kat, bazıları 25-30, bazıları ise 30-40 kez pasajlama yapılabileceğini belirtmişlerdir (Apel ve ark., 2009).

\section{Dielektroforez}

Dielektroforez (DEP) elektrik alan gradyanları tarafindan oluşturulan elektriksel olarak polarize edilebilir parçacıkların hareketini sağlayan ve 
hücreleri içsel elektro-fiziksel özelliklerine göre ayıran bir tekniktir (Pethig ve ark., 2010). DEP alternatif akım elektrik alanının kullanıldığı hücrelerin ve bunları çevreleyen sıvının elektriksel polaritelerindeki farklılıkların kullanılarak hücrelerin manipüle edildiği ve ayrıştırılabildiği bir sistemdir. Aynı zamanda elektriksel özellikleri kullandığı için biyokimyasal etiketlemelere ihtiyaç duymadan hücre alt kümelerinin de tanımlanmasında kullanılan ideal bir yöntemdir. Genellikle heterojen yapıdaki hücresel popülasyonları ayırt etmek için kullanılır (Ismail ve ark., 2015). Özellikle hematopoietik kök hücreleri (CD34 antijeni olarak tanımlanan) ve kandaki farklılaşmış türevlerini bunun yanında adipoz dokudaki mezenkimal kök hücreleri ayırt etmek için kullanılan bir tekniktir. Bir hücre elektrik alanına yerleştirildiğinde polarize olur ve bir çift kutup oluşturur. Düzgün olmayan bir elektrik alanına yerleştirildiğinde hücre boyutu, yüzey yükü, nükleik asit içeriğine bağlı olarak tek yönde harekete neden olan net bir kuvvet oluşur (Zhu ve Murthy, 2013). İndüklenen elektriksel momentumun polaritesine bağlı olarak hücreler 2 farklı şekilde hareket ederler. $\mathrm{Bu}$ etkiler pozitif DEP ve negatif DEP olarak isimlendirilirler. Pozitif DEP hücrelerin yüksek elektiriksel alanların ve değişimlerin olduğu elektrotlara yakın alanlara doğru hareket etmesini sağlar. Negatif DEP ise hücrelerin elektrotlardan uzak alanlara hareket etmesini sağlar. Bu sayede iki hücre popülasyonun farklı DEP yanıtı vermesiyle hücreler farklı dielektroforetik profillerine ayrilabilirler (Pethig ve ark., 2010; Ismail ve ark., 2015).

\section{Alan akışlı fraksiyonlama}

Alan akışlı fraksiyonlama (FFF) hücre popülasyonu içinde bulunan canlı hücrelerin sahip oldukları morfolojik ve biyofiziksel farklılıklar ile farklı fraksiyonlara ayrılmalarını sağlar. FFF işlemi sırasında hücrelerin özellikleri ve işlevleri korunur (Roda ve ark., 2009a). FFF, laminer bir akış içeren kılcal ve boş bir alanda mobil bir faz içerisine analitin dikey olarak eklenmesi sonucu mobil faz ile etkileşim göstermesi prensibine dayanır. Mobil faz numune içerisinde bulunan bileşenlerin kanaldan aşağıya doğru hareket etmesini sağlar. Hücrelerin sahip oldukları alan, boyut ve yüzey özelliklerindeki farklılıklar sebebiyle numunelerin laminer akışı dik olarak uygulanır ve bu da farklı hücrelerin farklı tutanma süresi göstermesine sebep olur. Bu sayede hücre popülasyonu arasında ayrım yapılması sağlanır (Roda ve ark., 2009b).

FFF çalışma prensibi olarak sıvı kromatografik yöntemlere benzemektedir, numune bir kanal boyunca hareket ettirilir ve karakterizasyonu sağlamak için bir dedektör veya toplama cihazına aktarılır. Siv1 kromatografik yöntemlerden farklı olarak FFF de sabit faz bulunmaz. FFF numunenin makromoleküllerin ve mikrometre düzeyinde parçacıkların elüsyonlarının hareketini sağlar. Numunelerin oluşan parabolik akış sayesinde birikim duvarına doğru itilmesiyle duvara olan uzaklığı azalır ve bu da numunenin konsantrasyonun artmasını sağlar. Artan konsantrasyon bir konsantrasyon gradyanı oluşmasını sağlar. Birbirine zıt gerçekleşen bu iki işlem dengelendiğinde oluşan numune bulutu ortalama bir yüksekliğe sahip olur. Numunenin molar kütlesi veya boyutu ne kadar küçükse bulut yüksekliği o oranda yüksek olur ve kanaldan çıkma süresi kısalır (Reschiglian ve ark., 2005).

FFF yönteminin farklı alt teknikleri bulunur. En eski alt teknik termal FFF'dir. Termal FFF'de alan farkı sıcaklık ile oluşturulur. Kanalın bir tarafı 1sıtılır diğer tarafı ise soğutulur. Bu sayede kanalın 
üst ve alt duvarları arasında uygulanan küçük sıcaklık farkı yüksek termal gradyan üretir. Kullanılan alt tekniklerin en basit örneği yerçekimi etkisini kullanan yerçekimsel alan akış fraksiyonudur (GrFFF). Bu alt tekniğin hücrelerin mikrometre boyutunda çeşitli partiküllerden ayrılmasında ve karakterizasyonunda başarılı olduğu bildirilmiştir. Bir diğer alt teknik, GrFFF'ye benzer prensiple çalışan hücreleri ayırmak ve saflaştırmak için merkezkaç kuvvetini kullanan sedimantasyon FFF'dir (SdFFF). FFF'nin kök hücrelerde ilk kez 1996 y1lında fare kemik iliğinden kök hücrelerin izolasyonunda GrFFF alt tekniği ile yapıldığı bildirilmiştir (Kowalkowski ve ark., 2006).

İnsan vücudunda kök hücre çeşitliliğinin az olduğu bildirilmiştir. $\mathrm{Bu}$ sebeple karmaşık hücre popülasyonları arasında kök hücrelerin izolasyonları için immünolojik belirteçler ve etiketlemelerden yararlanılır. $\mathrm{Bu}$ etiketlemeler için manyetik bir boncuk veya floresanla etiketleme gibi teknikler kullanılır. Bu teknik kök hücrelerin izolasyonu için avantajlar sağlarken bazı dezavantajları beraberinde getirebilir. Örneğin bir kök hücrenin etiketlenmesi kök hücrelerin farklılaşma süreçlerini engelleyebilir ayrıca pluripotent kök hücreler için spesifik belirteçler mevcut değildir. Bu sebeple FFF yöntemi bu dezavantajların giderilmesi için kullanılabilecek önemli bir yöntemdir (Reschiglian ve ark., 2005).

\section{Akış sitometrisi}

Akış sitometrisi (FACS), monoklonal antikorlara konjuge edilen floresan boyalar ile boyanmış farklı tiplerdeki hücrelerin hızlı bir şekilde incelenmesine olanak sağlar. Her hücre biyokimyasal ve antijenik açıdan farklı özellikler gösterdiği için ayrı ayrı değerlendirilir (Preffer ve Dombkowsk, 2009). Bu yöntem akan bir sıvı içerisindeki hücrelerin özelliklerinin incelenmesi şeklinde özetlenebilir.
FACS yönteminin temeli hücrelerin boyutu, şekli, DNA ve RNA içeriği ve stoplazmik içeriği yönünden incelenmesidir. Bunun için hedef yap1 veya hücre öncelikle floresan madde ile işaretli bir antikor veya özel fluoresan yapıdaki bir madde (antikor veya nükleik asitlere özel propidium iodide gibi özel bir boya) ile işaretlenir (Kanev ve Muranlı, 2016). FACS bir 1şık kaynağından geçen bir sıvı akışındaki mikroorganizmalar, çekirdekler ve kromozomlar gibi tek bir hücrenin veya diğer partiküllerin sahip olduğu optik ve floresan özelliklerini ölçme yeteneğine sahiptir. Antikorlarla veya boyalar ile işaretlenen hücrelerin boyutu, tanecikliği ve floresan özellikleri de hücreleri analiz etmek ve farklılaştırmak için kullanılan parametrelerdir (Adan ve ark., 2017).

Lazer demetinin içinden geçen her bir hücre veya partikül lazer ışının sapmasına neden olur. Hücreler tarafından yayılan fluorosen 1şınlar bir araya getirilir ve optik filtreler aracılı̆̆ıla sahip oldukları farklı dalga boylarına göre ayrılırlar ve analog sinyaller elde edilir. Fluorosen antikorlar hücrelerin sahip oldukları spesifik yüzey reseptörlerinin yoğunluğunun tespit edilmesini sağlar. $\mathrm{Bu}$ sayede farklılaşmış hücre tipleri ve bunların alt populasyonlarıda tespit edilir (Karaboz ve ark., 2008).

FACS yöntemi heterojen hücre popülasyonları arasında hücrelerin ve bunların bileşenlerinin kantitatif özelliklerini hızlı bir şekilde analiz edilmesini sağlar. Kök hücrelerin izole edilebilmesi için monoklonal antikorların kullanıldığı immünfenotiplendirme yöntemi kullanılır. Monoklonal antikorlar kullanılarak kök hücrelerin yüzeylerinde bulunan spesifik belirteçler saptanabilir. $\mathrm{Bu}$ antikorlarla istenen antijenik yapının varlığı ya da yokluğu belirlenebilir (Kanev ve Muranl1, 2016). 


\section{Manyetik aktif hücre sıralama}

Manyetik aktif hücre siralama (MACS) tekniği hücrelerin yüzeyinde bulunan yüzey belirteçlerine dayalı hedef hücrelerin yüksek verimle tanımlanmasına olanak sağlar. Biyoteknolojide in vitro çalışmalarda hücre temelli geliştirilen tedavide geniş bir uygulama alanı bulmuştur. Hücre temelli yapılan çalışmalarda yüksek saflık, geri kazanım ve verimli biyomedikal uygulamalar için kritik öneme sahiptir. Özellikle FACS yöntemi heterojen karışımlar içerisinde hücrelerin sahip olduğu birden çok optik parametreyi eşzamanlı olarak ölçerek spesifik izolasyonlar yapabilmesi bu yöntemi önemli bir araç haline getirmiştir. Bununla birlikte her hücre için kantitatif ölçüm gerektirmesi bir dezavantaj oluşturur. MACS yöntemi ise bunun aksine manyetik olarak etiketlenmiş hedef hücrelerin yüksek verimle ayrılmasına olanak sağlar (Adams ve ark., 2008).

MACS yöntemi ile hücrelerin farklılaşma gruplarına göre farklı hücre türleri izole edilir. \%90’nın üzerinde saflık istenen durumlarda hücre popülasyonlarının izolasyonunu sağlayabilir. Hücrelerin izolasyonun için monoklonal antikor, enzim, lektin veya streptavidin ile kaplanan manyetik boncuklar hücre yüzeylerinde bulunan yüzey antijenlerine bağlanırlar. Daha sonra hücre süspansiyonları manyetik alana yerleştirilir. Etiketlenmemiş hücrelerin yıkanması sağlanarak uzaklaştırılır ve manyetik alanda kalan etiketlenmiş hücreler yakalanır. Manyetik alanın kapatılması sonucu etiketlenen hücreler elde edilir (Kaur ve ark., 2019; Zeb ve ark., 2019).

MACS yönteminin pozitif ve negatif ayırma olmak üzere iki ayırma tekniği bulunur. Pozitif ayırma tekniğinde normal çalışma prensibine göre etiketlenmemiş hücreler yıkanarak uzaklaştırılır, istenen hücrelerin bağlanması için ise antikor ile kaplı manyetik boncuklar kullanılır. Negatif ayırma tekniği ise genellikle türe özgü maddelerin mevcut olmadığı durumda kullanılır. İşlem görmemiş hücreler antikor kokteyli ile kaplanır böylece etiketlenmemiş hücreler yakalanırken etiketlenen hücrelerde yıkanarak toplanabilir (Zeb ve ark., 2019).

Kök hücre çalışmalarında özellikle kemik iliği, göbek kordonu kanı ve lipoaspirat örneklerinden elde edilen MSC popülasyonun izole etmek için kullanılmıştır. Bunun yanında MSC'lere benzer özellik gösteren kemik iliği stromal kök hücrelerin de izolasyonu için bu yöntemin kullanıldığı bildirilmiştir. $\mathrm{Bu}$ kök hücrelerin izolasyonu için yüzeylerinde bulunan CD106 antijenin işaretleyicisi STRO-1 kullanılmıştır. STRO-1 kök hücrelerin eritrositlerden ve lenfositlerden ayrılmasına olanak sağlar. Bunun dışında CD11b, CD34 ve CD45 gibi antijenlerin kök hücrelerin MACS yöntemiyle izolasyonunda hedef olarak seçilebileceği bildirilmiştir (Markides ve ark., 2019).

\section{Yeni yöntemler}

Kök hücre izolasyonunda yüksek saflıkda hücre elde etmek, izolasyon işlemini basitleştirmek ve seri üretimin sağlanması amaciyla yeni izolasyon yöntemleri ortaya çıkmaktadır. Yeni yöntemler mevcut yöntemlerin geliştirilmesi veya yeni bir prensibin oluşturulmasına dayanır (Zhu ve Murthy, 2013).

\section{Sıcaklığa duyarlı iki fazlı sistem}

Yeni bir yöntem olan bu sistem sicaklık farkına dayalı kök hücrelerin izole edilebilmesini sağlar. Sıcaklığa duyarlı bir polimer olan poli (Nizopropilakrilamid) (PNIPAAm) oda sıcaklığında $\left(20^{\circ} \mathrm{C}\right)$ suda çözünebilirken, $32-35^{\circ} \mathrm{C}$ de ise sulu 
çözeltilerde çöker. Kök hücreye özgü spesifik belirteçleri tanıyan PNIPAAm ile konjuge edilen antikorlar kullanılarak hücrelerin izolasyonu sağlanır. Sıcaklık $20^{\circ} \mathrm{C}^{\prime} \mathrm{den} 32-35^{\circ} \mathrm{C}^{\prime}$ ye yükseltilerek sulu çözeltiden çöktürülebilir. $\mathrm{Bu}$ sayede sulu çözeltide çökelmiş hücreler polietilen glikol (PEG) (üst faz) ve dekstran (alt faz) tarafindan oluşturulan iki fazlı bir yoğunluk farkında santrifüjleme ile diğer hücrelerden ayrılabilir. Hedef hücreler iki fazın arasında tortu şeklinde bantlar halinde bulunurken, diğer hücreler ise alt kısımda toplanır (Zhu ve Murthy, 2013).

\section{Eksponansiyel zenginleştirme ile sistematik ligand geliştirme}

Eksponansiyel zenginleştirme ile sistematik ligand geliştirme (SELEX) hedeflenen hücrelerin izolasyonu için hedeflerine üç boyutlu şekillerinden dolayı yüksek seçicilik ve duyarlılıkla bağlanan oligonükleotidler (RNA veya ssDNA) olan aptamerlerin kullanıldığı bir yöntemdir. Bu yöntem ile herhangi iki hücre tipi arasındaki yüzey moleküllerinin ekspresyonun arasındaki farklılıklar belirlenebilir. Genellikle eritrositlerin, kanser hücrelerinin ve kök hücrelerin izolasyonunda kullanılır. Aptamerler 15-60 bazdan oluşan aminoasit, peptit, protein, nükleozit, bazı ilaçlar ve mikroorganizmalar gibi farklı hedeflere yüksek özgünlükte bağlanabilme yeteneği bulunan RNA ve DNA oligonükleotitleridir. Üç boyutlu ve kıvrımlı bir yapıya sahiptirler. Hedef molekülleriyle aralarında hidrojen bağları, elektrostatik etkileşimler ve Van der Waals etkileşimleri oluşturarak hedef yapıya bağlanabilirler. Aptamerler antikorlara benzer şekilde hedef moleküllere yüksek afinite ve özgüllük gösterirler. Bunun yanında hem 1S1 denatürasyonuna hem de indirgeme koşullarına karşı dayanıklılık gösterir (Didar ve Tabrizian, 2010).
SELEX tabanlı hücre izolasyonuna başlamak için öncelikle DNA ya da RNA ile hazırlanan yaklaşık $10^{16}$ oligonükleotit içeren bir oligonükleotit kütüphanesi hazırlanır. Elde edilen kütüphane rastgele dizilmiş 40-80 nükleotit uzunluğunda bir merkez bölgeye sahip olan DNA ya da RNA parçalarıyla hazırlanır ve kütüphane PCR ile çoğaltılır. Daha sonra aptamerler kök hücre popülasyonu ile inkübe edilirler. Bağlanmayan aptamerler uzaklaştırılır. Bağlanan aptamerler daha sonra hücre yüzeylerinden ayrıştırılır. Bir sonraki SELEX döngüleri için RT-PCR ile tekrar çoğaltılır. DNA ve RNA havuzlarının istenmeyen bölgelerine spesifik bağlanmaları önlemek için önceden belirlenen DNA ve RNA havuzu kontrol hücrelerine maruz bırakılır. Her bir döngü SELEX turu olarak ifade edilmektedir ve 10-12 tekrar sonrasında hedef moleküle yüksek afinite bağlanabilen DNA dizileri elde edilmiş olur. Hedef seçme ve çıkarma işlemlerinden sonra homojen aptamer popülasyonda spesifik olarak hedef hücreye bağlanır. Spesifik aptameri tespit etmek için mikroakışkan cihazlar kullanılır. Bu cihazlar seçim sürecinin hızlı, verimli ve otomatik hale getirirler (Stoltenburg ve ark., 2007; Ohuchi, 2012; Bayraç ve Kandemir, 2018).

\section{Mikroakışkanlar}

Mikroakışkan sistemler kök hücre izolasyonunda da kullanılan, cihazların ve sistemlerin küçültülmesini amaçlayan yeni bir uygulama alanıdır. Bu sistemler istenen mikro çevreyi elde etmek için mikrometre ölçeğe kadar olan sıvı akışlarını hassas şekilde manipüle ederler. Bu sayede kök hücrelerin kültürü, düzenlenmesi ve izolasyonu için önemli araçlar haline gelmişlerdir. Geliştirilen mikroakışkan cihazlar kök hücre analizleri dışında hastalıkların teşhisi, ilaç taraması, metabonomi, doku mühendisliği ve diğer biyolojik uygulamalar gibi 
çok sayıda alanda yaygın olarak kullanılırlar (Zhang ve ark., 2017).

Mikroakışkan sistemlerde hedef in vitro ortamların mikro düzeyde taklit edilmesidir. Optik şeffaflık ve geliştirilen protokollerin otomatik hale gelmesi gibi avantajlara sahiptirler. Bu sayede mikro ortamlarda incelenen hücrelerin morfolojileri ve işlevleri sistematik olarak incelenebilir ve gerçek zamanlı olarak taranabilir (Wu ve ark., 2011). Diğer avantajları ise küçük boyutlara sahip olması sebebiyle reaksiyon hızlarının ve analiz sürelerinin azalması, reaktiflerin ve analitlerin tüketiminin azalması, potansiyel olarak olabilecek zararlı yan ürünlerin üretiminin azalması ve tek bir çip üzerinde birden fazla test veya birden fazla entegre işlem yapabilmesidir (van Noort ve ark., 2009).

\section{KÖK HÜCRELERIN TEDAVIDE KULLANIMI}

Kök hücre alanındaki ilerlemeler geleneksel ilaçlarla tedavi edilemeyen hastalıkların tedavisinde hücre temelli yöntemlerin ön plana çıkmasını sağlamıştır. Kök hücreler monoklonal antikorlara benzer şekilde kullanılarak kişiye özel bir tedavi seçeneği sunmaktadır. Kök hücrelerin sahip olduğu farklılaşma yeteneği rejeneratif tıp olarak isimlendirilen bu alanın sınırlarının genişlemesini sağlamıştır. Kök hücreler rejeneratif tıpda doku rejenerasyonunu sağlayarak, patojenlerin ve kötü huylu hücrelerin immünizasyonu için otolog, allojenik ve singenik olarak kullanılabilirler (Mahla, 2016; Kaya ve Tutun, 2021).

\section{Multipotent kök hücrelerin tedavide kullanımı}

$\mathrm{Bu}$ hücreler çeşitli hastalıkların tedavisinde antiinflamatuar ve antiapoptotik etkilere yol açarak bir dizi hücresel veya mekanik yolu aktive edebilirler. $\mathrm{Bu}$ hücresel ve moleküler yolakların inhibe edilmesi veya aktivasyonu ile terapötik etkiler sergilediği bildirilmiştir (Mirzaei ve ark., 2017).

Multipotent kök hücreler dokularda meydana gelen hasar sonucu kemokin miktarını ve buna bağlı olarak kemokin reseptörlerinin ekspresyonun artması sebebiyle hasarlı bölgeye göç edebilecekleri bildirilmiştir. Oluşturulan hayvan modellerinde omurilik yaralanması, kemik kırığı, otoimmün bozukluk, romatoid artrit ve hematopoetik bozukluklar gibi farklı hastalıkların tedavisinde multipotent kök hücreler uygulamalarının başarılı olabileceği belirtilmiştir (Sobhani ve ark., 2017).

Kardiyovasküler hastalıklar: Multipotent kök hücreler miyokard dokusunda meydana gelen hasarın giderilmesi ve dokunun yenilenmesini sağlar. Yapılan denemelerde miyokardiyal perfüzyonu ve skar dokusunu iyileştirdiği, kardiyomiyositlerin yenilenmesini hızlandırdığı ve endojen progenitör hücrelerin aktivasyonunu sağladığ 1 belirtilmiştir. $\mathrm{Bu}$ etkileri ile sistolik ve diyastolik hacimler gibi kardiyak fonksiyonun önemli derecede iyileşmesini ve kalp yetmezliği gelişimini azalttığı görülmüştür (Miyahara ve ark., 2006). Bir başka çalışmada ise amniyotik kök hücrelerin terapötik potansiyeli ortaya konmuştur. Amniyotik kök hücreler koroner arterlerde ligasyon uygulanarak iskemi oluşturulan sıçanlarda uygulanmıştır. Kök hücre tedavisi sonucu miyokardiyal hücre ölümünün önlendiği ve dokuda nekroz gelişiminin azaldığı belirtilmiştir (Bollini ve ark., 2011).

Köpeklerde enfarktüs sonrası ölü miyokard dokusunun kardiyak progenitör hücreleri içerip içermediğini belirlemek için yapılan bir çalışmada ise hepatosit büyüme faktörü (HGF) ve insülin benzeri büyüme faktörü 1 (IGF-1) ile aktive edilen kök hücreler aracılığıyla enfarktüslü kalbin 
iyileştirilebileceği ortaya konmuştur. Bu çalışmada kalpteki kardiyak kök hücrelerin varlığı yüzeylerinde eksprese ettikleri c-kit, MDR-1 ve Sca1 yüzey antijenlerinin tespit edilmesiyle belirlenmiştir. Enfarktüsün oluşumundan sonra kalpte bulunan kardiyak kök hücrelerin aktivasyonunu sağlamak için HGF ve IGF-1 enfarktüsün oluştuğu komşu miyokardiyuma enjekte edilmiştir. IGF-1 ve HGF ilgili hücreler tarafından eksprese edilmekte ve göç, çoğalma ve hayatta kalmalarını aktive ederler. İmplantasyonun ardından ekokardiyografik ve yapisal parametler incelenmiştir. Elde edilen veriler sonucunda büyüme faktörü uygulanan grubun büyüme faktörü uygulanmayan gruba kıyasla progenitör hücrelerin sayısı artmıştır (Linke ve ark., 2005). HGF’nin damar büyümesini ve miyokadiyal rejenerasyonu arttırdığı bildirilmiştir. IGF-1' in uyarılması ise hücre ölümlerinin önüne geçer ve kardiyomyositlerin farklılaşmasını indükler (Reiss ve ark., 1996).

Otoimmün hastalıklar: In vitro denemelerde amniyotik kök hücrelerin hematopoetik hücrelere farklılaşma yeteneğine sahip olduğu tespit edilmiştir. İmmün yetmezliği olan farelerde amniyotik kök hücre transplantasyonundan 4 ay sonra bu kök hücrelerden farklılaşan makrofaj, doğal öldürücü hücre, B ve T lenfositlerinin varlığ1 tespit edilmiştir. $\mathrm{Bu}$ sonuçlar multipotent yapıdaki amniyotik kök hücrelerin hematopoetik sistemde immünmodülasyon sağlayarak otoimmün hastalıkların tedavisinde kullanılabileceğini göstermiştir (Ditadi ve ark., 2009).

Deneysel bir fare modeli üzerinde yapılan bir çalışmada farelerde deneysel otoimmün ensefalomiyelit oluşumu indüklenmiş ve mezenkimal multipotent kök hücreleri tedavi amacıyla kullanılmıştır. Multipotent kök hücreler hastalığın indüklenmesinden önce koruyucu amaçlı olarak ve hastalığın oluşumu sırasında uygulanmıştır. Her iki dönemde de $1 \times 10^{6}$ hücre intravenöz olarak uygulanmıştır. Uygulanan kök hücreler farelerin tibia ve femurlarında bulunan kemik iliğinden izole edilerek hazırlanmıştır. Yapılan çalışma sonucunda multipotent kök hücreler hem anti-CD3 veya anti-CD28 ile aktive edilen farelerde, hem de miyelin oligodendrosit glikoproteini (MOG) ile uyarılmış farelerde oluşan T hücre yanıtlarının inhibe edilmesini sağlamıştır. Buna bağlı olarak multipotent kök hücrelerin farelerde $\mathrm{T}$ hücresi aracılı deneysel otoimmun ensefalomiyeliti tedavi ettiği bildirilmiştir (Zappia ve ark., 2005).

Diyabet: Diyabet dünya üzerinde her yaştan insanda görülebilen kronik bir hastalıktır. Son yıllarda diyabet tedavisi için düzenli insülin enjeksiyonu, insülin pompasının kullanımı, Beta hücresi veya pankreas nakli gibi yöntemler kullanılmaktadır. Yapılan çalışmalar multipotent hücrelerin diyabet tedavisinde kullanılabileceğini göstermiştir. Amniyotik kök hücrelerin uygulandığ 1 diyabetik farelerde insülin ve GLUT-2 mRNA'nın ekspresyonun arttığı ve kan glikoz seviyesinin düştüğü gözlenmiştir. Buna bağlı olarak da vücut ağırlıkların normal seviyelere düştüğü belirtilmiştir. Amniyotik kök hücrelerin insülin ve glukagon üreten hücrelere farklılaşarak bu hormonların seviyelerinin yükselmesini sağlamıştır. Bu etkileri ile diyabet tedavisinde kullanılabileceği belirtilmiştir (Wei ve ark., 2003; Sobhani ve ark., 2017).

Karaciğer yetmezliği: Karaciğer dokusu, parankiminde oluşabilecek bir yıkımlanma sonrasında güçlü bir rejenerasyon potansiyeline sahiptir. Bazı durumlarda rejenerasyon kapasitesi yetersiz kalır ve karaciğer yetmezliği meydana gelir. Oluşan karaciğer hasarının giderilmesi ve rejenerasyonun desteklenmesi amaciyla mezenkimal 
kök hücrelerin kullanımı için çalışmalar yapılmıştır. MSC'lerin hepatositler rejenerasyon sağladığı, immünomodülatör ve antiinflamatuar yanıtları indüklediği belirtilmiştir. Ayrıca proinflamatuar fibrinojenik sitokin aktivitesini inhibe ederek ve apoptozisi azaltarak etkili olmuştur. Ayrica, MSC'lerin epidermal büyüme faktörü (EGF) salgılayarak hepatosit proliferasyonunu ve fonksiyonunu sağladığı belirtilmiştir (de Miguel ve ark., 2019).

Klinik denemelerde MSC'ler intravenöz (IV), intrahepatik (portal ven veya hepatik arter aracılığıyla) ve intrasplenik gibi çeşitli yollarla hastalara nakledilmiştir. IV enjeksiyon kolay uygulanabilirliği sebebiyle klinik uygulama için en çok kullanılan yoldur. Uygulama kolaylığına rağmen, uygulanan hücrelerin 1-2 saat içerisinde yaklaşık \%60’lık kısmının akciğerde birikebileceği ve immün sistem hücreleri tarafından temizlenmesi sebebiyle karaciğere ulaşamayacağı bildirilmiştir. İtraportal enjeksiyon ise daha hızlı uygulama ve hedef doku dışında birikimin olmaması sebebiyle MSC'lerin karaciğer hastalıklarında kullanımı için en uygun yoldur. İntraspleknik yöntem ise en az kullanılan uygulama yoludur (Yang ve ark., 2020).

Solunum yolu hastalıkları: Solunum yolu hastalıkları hafif soğuk algınlığı gibi hastalıklardan pnömoni, pulmoner emboli, akut astım ve akciğer kanseri gibi tehlikeli hastalıklara kadar çeşitlilik gösterebilir. $\mathrm{Bu}$ haslıkların tedavisi için bronkodilatörlerin kullanımı, organ nakli ve rejenerasyonun sağlanması gibi seçenekler mevcuttur. MSC'ler sahip oldukları rejenerasyon kapasitesi ile obstrüktif bronşiolit, idiyopatik pulmoner fibroz ve KOAH gibi kronik akciğer hastalıklarının tedavisinde terapötik bir ajan olarak kullanılabilirler. Plasental ve kemik iliğinden elde edilen MSC'ler endoktoksin veya bakteriyel kaynaklı gelişen akciğer doku hasarında inflamasyonu ve doku hasarını azalttığ belirtilmiştir. Ayrıca, endojen kök hücrelerin hasarlı bölgeye ulaşması ve lokal kök hücrelerin ise farklılaşma sinyallerinin oluşturulmasıyla akciğer dokusunda rejenerasyonu başlattığı düşünülür. MSC'ler tarafindan salgılanan stromal hücrelerden üretilen faktör (SDF-1) ismi verilen kemokinin anjiogenesi sağladığı ve MSC'lerin rejeneratif etkilerine aracılık ettiği belirtilmiştir. Bununla birlikte inflamatuar sitokinlerin ve büyüme faktörlerinin üretiminin baskılanmasıyla antiinflamatuar ve koruyucu etki gösterirler (Hosseinirad ve ark., 2018).

İnfeksiyöz hastalıklar: Farklı yüzeylerde veya doku implantlarında oluşan biyofilmleri tedavi etmek için tek başına antibiyotik kullanımının yeterli olmadığı ve antibiyotiklerle beraber alternatif tedavi seçeneklerine de ihtiyaç olduğu bildirilmiştir (Johnson ve ark., 2017). Yapılan çalışmalarda mezenkimal kök hücrelerin fagositlerin aktivitelerini ve antimikrobiyal peptitlerin aktivitelerini arttırarak antimikrobiyal etkinlik gösterdiği bildirilmiştir (Krasnodembskaya ve ark., 2012; AlcayagaMiranda ve ark., 2015).

Farelerde oluşturulan kronik bir Staphylococcus aureus enfeksiyonunda MSC'lerin etkisi antibiyotiklerle beraber değerlendirilmiştir. $\mathrm{Bu}$ çalışmada tedavi edilmeyen kontrol grubu, sadece antibiyotik uygulanan grup, sadece MSC uygulanan grup, aktive edilmiş MSC uygulanan grup, MSC ile beraber antibiyotik uygulanan grup ve aktive edilmiş MSC ile birlikte antibiyotik uygulanan grup olmak üzere 6 farklı grup oluşturulmuştur. Antibiyotik olarak amoksisilik-klavulanik asit oral yoldan, MSC'ler ise sistemik olarak uygulanmıştır. Uygulama sonunda Toll benzeri reseptör 3 (Toll Like Receptor 3-TLR3) ligandı ile aktive edilmiş 
MSC ile beraber antibiyotik uygulanan grupta yapılan biyolüminesans görüntüleme ve kültür yoluyla bakteri sayımına dayalı olarak yara bölgesinde bakteri yükünü önemli ölçüde azaltan tek tedavi olduğu bildirilmiştir (Johnson ve ark., 2017).

\section{Pluripotent kök hücrelerin tedavide kullanımı}

Pluripotent kök hücreler sonsuz sayıda çoğalma ve üç embriyonik germ katmanını da farklılaşma yeteneğindedir. Bu özellikleri ile çeşitli hastalıkların tedavisinde kendisine yer bulmuştur. Klinik kullanım için iki tip pluripotent hücre kullanılır. Bunlar embriyonik kök hücreler ve iPSC'lerdir. İnsan embriyonik kök hücreleri (hESC) ile omurilik yaralanmaları, yaşa bağlı makula dejenerasyonu ve tip 1 diyabet gibi çeşitli hastalıkların ve yaralanmaların tedavisi için araştırmalar sürmektedir. HESC'lerin klinik kullanımıyla ilişkili olarak iki endişe mevcuttur. Bunlar; insan embriyolarının kullanılmasıyla ilgili etik sorunlar ve kök hücre tedavisinin ardından oluşabilecek bağışıklık reddidir. Bağışıklık reddinin giderilebilmesi için araştırmacılar nükleer transfer yoluyla hastanın kendi somatik hücrelerinden hESC üretmek için çalışmalar yapmışlardır. Bu amaçla ilk çalışmalardan biri 1996 yılında koyun Dolly üzerinde yapılmıştır. Dolly üzerinde yapılan çalışmaların olumlu sonuçlar vermesi bilim insanlarının bu alana yönelmelerini sağlamıştır. Bu doğrultuda somatik hücrelere Oct3/4, Sox2, Klf4 ve cMyc gibi yeniden programlama faktörlerinin aktarılmasıyla pluripotensin indüklendiği belirtilmiştir ve bunun sonunda iPSC'ler elde edilmiştir. İnsan iPSC'leri ilk kez 2007 yılında üretilmeye başlanmıştır. O tarihten günümüze kadar birçok araştırmacı iPSC'lerin hastalar üzerinde kullanımı konusunda çalışmalarını sürdürmektedir
(Takahashi ve ark., 2007; Freund ve ark., 2010; Yamanaka, 2020).

Diyabet: Son yıllarda biyoteknolojik ürünlerdeki gelişim diyabet tedavisi için yeni stratejilerin ortaya çıkmasına sebep olmuştur. Bunlar gen terapisi, doku mühendisliği ve hücre terapisidir. $\mathrm{Bu}$ doğrultuda kök hücrelerin farklılaşması ile insülin salgılayan hücrelerin veya adacıkların transplantasyonuna dayanan yeni prosedürler geliştirilmiştir (Liras ve ark., 2013).

IPSC'ler ile $\beta$ hücrelerinin üretimi ilk olarak 2008 y1lında gerçekleştirilmiştir. In vitro olarak dört aşamalı bir prosedürle insan dermal fibroblast hücrelerinden türetilmiş iPSC'ler fonksiyonel insülin üretme yeteneğine sahip adacık benzeri (ILC) hücrelerine farklılaşmıştır. $\mathrm{Bu}$ hücreler glikoz stimulasyonuna yanıt olarak insülin salgılamış ve insülin miktarının doza bağlı şekilde arttırdı̆̆ belirtilmiştir (Tateishi ve ark., 2008; Soejitno ve Prayudi, 2011).

Tip 1 diyabet (T1DM) hastalarının deri fibroblast hücreleri kullanılarak yapılan bir başka çalışmada ise iPSC'lerin insülin üreten hücrelere farklılaşabileceği belirtilmiştir. DiPS (T1D-specific iPS cells) olarak da isimlendirilen bu hücreler hastaya özgü otolog bir hücre kaynağı olarak işlev görebilir ve bu sayede klasik allojenik kök hücrelerin sebep olabileceği bağışıklık reddinin oluşmasının önüne geçilebilirler (Maehr ve ark., 2009).

Tip 2 (T2DM) diyabet modelinin oluşturulduğu farelerde intraportal yolla karaciğer parankimine iPSC'lerin uygulanmasindan sonra insülin üreten P benzeri hücrelere farklılaştığı ve kan glikoz seviyelerini normal seviyelere düşürdüğü belirtilmiştir. Yapılan çalışmalarla oluşan P benzeri hücrelerin karaciğer parankimine stabil ve eşit bir şekilde dağıldığı bildirilmiştir. Bu nedenle iPSC 
hücresinden elde edilen insülin üreten $\mathrm{P}$ benzeri hücrelerin hem T1DM hem de T2DM fare modellerinde in vivo kan glikoz seviyesini normalleştirebildiği ve bu hastalıkların tedavisi için bir seçenek olabileceği belirtilmiştir (Soejitno ve Prayudi, 2011).

\section{Kardiyovasküler hastalıklar: İnsan} pluripotent kök hücrelerinin kardiyomyositlere farklılaşma yeteneğinin olduğunun belirlenmesi rejeneratif tıpta büyük bir ilgi uyandırmıştır. Ancak kalp dokusuna erişimin zor olması, fazla miktarda hücre popülasyonun elde edilememesi ve prosedürlerin karmaşı olması, insan kardiyomyositlerinin in vitro modeller üzerinde geliştirilmesinin önünde engel teşkil eder. $\mathrm{Bu}$ engellerin giderilebilmesi için bazı çözüm önerileri sunulmuştur. Bunun için yeni doğan hayvanların kardiyomiyositler izolasyonu ve bazı hedef proteinleri yüksek düzeyde eksprese eden yeni modeller sunulmuştur. $\mathrm{Bu}$ modellerin insan kardiyomiyositler kıyasla fizyolojik açıdan farklı1ıklar barındırması, yüksek maliyet ve çeşitli etik sorunları beraberinde getirmesi bu yöntemlerin sınırlı kullanımına neden olmuştur. Yapılan çalışmalarda aktif kardiyomiyosit hücrelerine farklılaşma yeteneğine sahip tek yetişkin kök hücrenin kardiyak progenitör hücreler olduğu belirtilmiştir (Lu ve ark., 2011).

Pluripotent kök hücrelerin kardiyomiyositler farklılaşması için Fibroblast büyüme faktörü (FGF), kemik morfogenetik proteini 2 ve 4 (BMP2, BMP4), Aktivin A, Wnt3a gibi spesifik büyüme faktörleri kullanılmaktadır (DeGeorge ve ark., 2008; Lu ve ark., 2011; Zhang ve ark., 2012).

Kardiyomiyositlerin transplantasyonu ile yapılan rejeneratif çalışmalarda deri fibroblastlarından elde edilen iPSC'lerin kalp yetmezliği olan sıçanlarda başarıyla uygulandığ belirtilmiștir. Miyokard infarktusu bulunan kobaylarda yürütülen bir başka çalışmada ise hücre transplantasyonundan sonra kalp fonksiyonlarının normal döndüğü ve ventriküler aritmilerin azaldığ belirtilmiştir. Hücrelerin kalp dokusuna transplantasyonu için doğrudan kalp içine uygulama ve hücre yaprağı teknolojisi kullanılmaktadır. Hücre yaprağı teknolojisi hücrelerin epikardiyuma nakledilerek çok katmanlı bir kardiyomyosit tabakası oluşturulması sağlanır. Miyokard dokusu elektriksel olarak yalıtkan bir yapıya sahip olduğu için bu yöntem ile alıcı kalbinin elektrofizyolojik senkronizasyonun bozulmamasını sağlamaktadır. (Kishino ve ark., 2020).

\section{Nörodejeneratif}

hastalıklar:

Nörodejeneratif hastalıklar motor nöron işlev kaybının veya merkezi sinir sistemindeki (MSS) nöronların progresif ve kontrolsüz bir şekilde ölümü ile şekillenir. Alzheimer (AD), Parkinson (PD), amyotrofik lateral skleroz (ALS) ve multipl skleroz (MS) gibi nöronlarda dejenerasyonla seyreden hastalıkların tedavisi için yeni terapötik stratejilere ihtiyaç vardır. Yapılan çalışmalarla iPSC'lerin kültür ortamında uzun süreli korunabilmesi, yeniden programlama faktörlerine maruz kaldıklarında farklılaşma yetenekleri, nörorejeneratif tıp ve nörolojik hastalıkların modellenmesi alanlarında umut verici terapötik yaklaşımlar sağlar. İPSC hücreleri kullanılarak MSS veya periferik sinir sisteminde etkin bir nöral populasyon oluşturmak için Rho ile ilişkili protein kinaz (ROCK) inhibitörü olan Y-27632 bileşiği kullanılarak embriyoid cisimciğin (EB) oluşumu sağlanır. Elde edilen bu yap1 kültür ortamında besleme ve doğrudan indüksiyon ile iPSC hücrelerinden nöral populasyonun oluşumunu sağlar (Kolagar ve ark., 2020). Ayrıca, dönüştürücü büyüme faktörü (TGF) inhibitörleri ve BMP sinyali kullanılarak nöral 
indüksiyon etkinliğini ve hızını büyük ölçüde artırılabileceği bildirilmiştir (Tabar ve Studer, 2014).

Yeniden programlama teknolojisi ile elde edilen iPSC hücreleri insanlarda nörodejeneratif hastalıkları modellemek ve tedavi etmek için önemli bir potansiyele sahiptir. Nörodejeneratif hastalıklarda hastaya özgü iPSC hücreleri (örneğin deri biyopsisinden izole edilerek hücrelere transkripsiyon faktörlerinin transferi ile türetilen) iki farklı şekilde kullanılabilirler. Bunlardan birincisi hastalığa neden olan mutasyonun bilindiği durumlarda (örneğin ailesel Parkinson hastalığı) DNA dizisini onarmak için gen hedefleme kullanılabilir. Gene göre düzeltilmiş hastaya özgü iPSC hücreleri daha sonra etkilenen nöronal alt tipe (örneğin, orta beyin dopaminerjik nöronlar) göre farklılaşmaya uğratılır ve hastanın beyin dokusuna nakledilir. Bir diğer kullanım yolu ise hastadan alınan hasarlı hücreler in vitro ortamda incelenir ve hücreler üzerinde potansiyel ilaçlar taranarak yeni terapötik bileşiklerin keşfedilmesine yardımcı olabilir (Robinton ve Daley, 2012).

Tablo 2. Kök Hücre Tedavisinde Kullanılan Onaylanmış Ürünler (Cuende ve ark., 2018).

\begin{tabular}{|c|c|c|c|}
\hline Kök Hücre & $\begin{array}{l}\text { Kök Hücre } \\
\text { Yapısı }\end{array}$ & Kullanıldığı Hastalık & $\begin{array}{l}\text { Onay Yılı ve Onay } \\
\text { Yeri }\end{array}$ \\
\hline Cellgram $\AA$-AMI & $\begin{array}{l}\text { Otolog Kemik } \\
\text { İliği Kaynaklı } \\
\text { Mezenkimal Kök } \\
\text { Hücre }\end{array}$ & $\begin{array}{l}\text { Akut Miyokard } \\
\text { İnfarktüsü }\end{array}$ & 2011- Güney Kore \\
\hline $\begin{array}{l}\text { HPC, Cord Blood } \\
\text { (Ducord) }\end{array}$ & $\begin{array}{l}\text { Allojenik Kordon } \\
\text { Kanı Kaynaklı } \\
\text { Hematopoietik } \\
\text { Kök Hücre }\end{array}$ & $\begin{array}{l}\text { Hematopoietik } \\
\text { Hastalıklar }\end{array}$ & 2012- Amerika \\
\hline Cartıstem ${ }^{\circledR}$ & $\begin{array}{l}\text { İnsan Göbek } \\
\text { Kordonu } \\
\text { Kanından } \\
\text { Türetilmiş } \\
\text { Mezenkimal Kök } \\
\text { Hücre } \\
\end{array}$ & $\begin{array}{l}\text { Osteoartritli hastalarda } \\
\text { diz kıkırdak } \\
\text { kusurlarının tedavisi }\end{array}$ & 2012- Güney Kore \\
\hline $\begin{array}{l}\text { HPC, Cord Blood } \\
\text { (Allocord) }\end{array}$ & $\begin{array}{l}\text { Allojenik Kordon } \\
\text { Kanı Kaynaklı } \\
\text { Hematopoietik } \\
\text { Kök Hücre }\end{array}$ & $\begin{array}{l}\text { Hematopoietik } \\
\text { Hastalıklar }\end{array}$ & 2013-Amerika \\
\hline Neuronata-R® & $\begin{array}{l}\text { Otolog Kemik } \\
\text { İliği Mezenkimal } \\
\text { Kök Hücre } \\
\text { Tedavisi }\end{array}$ & $\begin{array}{l}\text { Amyotrofik Lateral } \\
\text { Skleroz (ALS) }\end{array}$ & 2014- Güney Kore \\
\hline Holoclar & $\begin{array}{l}\text { Otolog İnsan } \\
\text { Kornea Epitel } \\
\text { Hücreleri }\end{array}$ & Kornea Hastalıkları & 2015- EMA \\
\hline Temcell HS & $\begin{array}{l}\text { Mezenkimal Kök } \\
\text { Hücre }\end{array}$ & GVHD & 2015- Japonya \\
\hline $\begin{array}{l}\text { Remestemcel-L } \\
\text { (Prochymal) }\end{array}$ & $\begin{array}{l}\text { İnsan Mezenkimal } \\
\text { Kök Hücre }\end{array}$ & $\begin{array}{l}\text { Akut graft-versus-host } \\
\text { hastalığ1 (GVHD) }\end{array}$ & 2015- Kanada \\
\hline
\end{tabular}


Tablo 2. (devami).

\begin{tabular}{|c|c|c|c|}
\hline Kök Hücre & $\begin{array}{l}\text { Kök Hücre } \\
\text { Yapısı }\end{array}$ & Kullanıldığı Hastalık & $\begin{array}{l}\text { Onay Yilı ve Onay } \\
\text { Yeri }\end{array}$ \\
\hline $\begin{array}{l}\text { HPC, Cord Blood } \\
\text { (Clevecord) }\end{array}$ & $\begin{array}{l}\text { Allojenik Kordon } \\
\text { Kanı Kaynaklı } \\
\text { Hematopoietik } \\
\text { Kök Hücre }\end{array}$ & $\begin{array}{l}\text { Hematopoietik } \\
\text { Hastalıklar }\end{array}$ & 2016- Amerika \\
\hline Stempeucel ${ }^{\circledR}$ & $\begin{array}{l}\text { Mezenkimal Kök } \\
\text { Hücre }\end{array}$ & $\begin{array}{l}\text { Buerger Hastalığına } \\
\text { Bağlı Ekstremite } \\
\text { İskemisi }\end{array}$ & 2016- DCGI \\
\hline MPC therapy & $\begin{array}{l}\text { Mezenkimal Kök } \\
\text { Hücre }\end{array}$ & $\begin{array}{l}\text { Sol Ventrikül Sistolik } \\
\text { Disfonksiyon }\end{array}$ & 2017- Amerika \\
\hline CEVA101 & $\begin{array}{l}\text { Otolog Kemik } \\
\text { İliği Kaynaklı } \\
\text { Kök Hücre }\end{array}$ & $\begin{array}{l}\text { Travmatik beyin } \\
\text { hasarı }\end{array}$ & 2017- Amerika \\
\hline Multistem & $\begin{array}{l}\text { Multipotent } \\
\text { Yetişkin } \\
\text { Progenitör Hücre }\end{array}$ & İskemik İnme & 2017- Amerika \\
\hline AST-OPC1 & $\begin{array}{l}\text { Pluripotent } \\
\text { Embriyonik Kök } \\
\text { Hücre }\end{array}$ & $\begin{array}{l}\text { Omurilik } \\
\text { Yaralanmaları }\end{array}$ & 2017- Amerika \\
\hline ATIR101 & $\begin{array}{l}\text { Hematopoietik } \\
\text { Kök Hücre }\end{array}$ & Ek İmmünoteröpatik & 2017- Amerika \\
\hline Ixmyelocel-T & $\begin{array}{l}\text { Mezenkimal Kök } \\
\text { Hücre }\end{array}$ & $\begin{array}{l}\text { İskemik Dilate } \\
\text { Kardiyomiyopatiye } \\
\text { Bağlı İlerlemiş Kalp } \\
\text { Yetmezliği }\end{array}$ & 2017- Amerika \\
\hline jCell & $\begin{array}{l}\text { Retina Progenitör } \\
\text { Hücreleri }\end{array}$ & Retinitis pigmentosa & 2017- Amerika \\
\hline $\begin{array}{l}\text { HPC, Cord Blood } \\
\text { (Hemacord) }\end{array}$ & $\begin{array}{l}\text { Allojenik Kordon } \\
\text { Kanı Kaynaklı } \\
\text { Hematopoietik } \\
\text { Kök Hücre }\end{array}$ & $\begin{array}{l}\text { Hematopoietik } \\
\text { Hastalıklar }\end{array}$ & 2018- Amerika \\
\hline Darvadstrocel (Alofisel ${ }^{\circledR}$ ) & $\begin{array}{l}\text { İnsan Mezenkimal } \\
\text { Kök Hücre }\end{array}$ & $\begin{array}{l}\text { Crohn hastalığ ile } \\
\text { ilişkili perianal } \\
\text { fistüller }\end{array}$ & 2018- EMA \\
\hline Cupistem ${ }^{\circledR}$ & $\begin{array}{l}\text { Otolog Yağ } \\
\text { Dokusu Kaynaklı } \\
\text { Mezenkimal Kök } \\
\text { Hücre }\end{array}$ & $\begin{array}{l}\text { Crohn hastalığ ile } \\
\text { ilişkili perianal } \\
\text { fistüller }\end{array}$ & 2018- Güney Kore \\
\hline Alofisel & $\begin{array}{l}\text { Allojenik Adipoz } \\
\text { Kök Hücre }\end{array}$ & $\begin{array}{l}\text { Crohn hastalığı ile } \\
\text { ilişkili perianal } \\
\text { fistüller }\end{array}$ & 2018- İsviçre \\
\hline Stemirac & $\begin{array}{l}\text { Mezenkimal Kök } \\
\text { Hücre }\end{array}$ & Omurilik Yaralanması & 2018- Japonya \\
\hline Romyelocel-L & $\begin{array}{l}\text { Hematopoietik } \\
\text { Kök Hücre }\end{array}$ & $\begin{array}{l}\text { AML'li hastalarda } \\
\text { bakteri ve mantar } \\
\text { enfeksiyonlarının } \\
\text { önlenmesi }\end{array}$ & 2018- Amerika \\
\hline CLBS14-RfA & $\begin{array}{l}\text { Hematopoietik } \\
\text { Kök Hücre }\end{array}$ & Refrakter anjina & 2018- Amerika \\
\hline CAP-1002 & $\begin{array}{l}\text { Allojenik Kök } \\
\text { Hücre }\end{array}$ & $\begin{array}{l}\text { Duchenne Musküler } \\
\text { Distrofi }\end{array}$ & 2018- Amerika \\
\hline
\end{tabular}

EMA: European Medicines Agency, DCGI: Drug Controller General of India. 


\section{SONUÇ}

Kök hücrelerin kendini yenileme ve adiposit, osteosit, kondrosit, nöron hücresi gibi farklı hücre tiplerine farklılaşma yeteneğinin bulunması hastalıklara karşı yeni bir rejeneratif stratejinin geliştirilmesini sağlamıştır. Bununla birlikte kök hücre biyolojisi üzerine yapılan çalışmalar kök hücre üretiminin ve izolasyonunun daha kolay ve anlaşılır olmasını sağlamıştır. Kök hücre teknolojisindeki bu ilerlemelerle hastalığa göre uygun kök hücre tipinin seçilmesi, kök hücrelerin farklılaşmasının daha uygun şekilde gerçeklemesi ve yan etkilerin azaltılması sağlanmıştır. Laboratuar ve klinik denemelerin olumlu sonuçlar vermesi rejeneratif tıpta kök hücreye olan ilgiyi daha da arttırmaktadır. Yakın gelecekte kök hücre uygulamalarının çok çeşitli hastalıkların tedavisinde kullanılması beklenmektedir.

\section{KAYNAKLAR}

Adams, JD., Kim, U., \& Soh, HT. (2008). Multitarget magnetic activated cell sorter. Proceedings of the National Academy of Sciences, 105(47), 1816518170.

Adan, A., Alizada, G., Kiraz, Y., Baran, Y., \& Nalbant, A. (2017). Flow cytometry: basic principles and applications. Critical reviews in biotechnology, 37(2), 163-176.

Alcayaga-Miranda, F., Cuenca, J., Martin, A., Contreras, L., Figueroa, FE., \& Khoury, M. (2015). Combination therapy of menstrual derived mesenchymal stem cells and antibiotics ameliorates survival in sepsis. Stem cell research \& therapy, 6(1), 1-13.

Andrzejewska, A., Lukomska, B., \& Janowski, M. (2019). Concise review: mesenchymal stem cells: from roots to boost. Stem Cells, 37(7), 855-864.

Apel, A., Groth, A., Schlesinger, S., Bruns, H., Schemmer, P., Büchler, MW., \& Herr, I. (2009). Suitability of human mesenchymal stem cells for gene therapy depends on the expansion medium. Experimental Cell Research, 315(3), 498-507.

Barky, ARE., Ali, EMM., \& Mohamed, TM. (2017). Stem cells, classifications and their clinical applications. American Journal of Pharmacology, 1(1), 001007.

Bayraç, AT., \& Kandemir, BB. (2018). Domuz Jelatinine Özgü DNA Aptamerlerinin Seçilimi ve Karakterizasyonu. Süleyman Demirel Üniversitesi Fen Bilimleri Enstitüsü Dergisi, 22(2), 774-778.
Bernemann, C., Greber, B., Ko, K., Sterneckert, J., Han, DW., Araúzo-Bravo, MJ., \& Schöler, HR. (2011). Distinct developmental ground states of epiblast stem cell lines determine different pluripotency features. Stem cells, 29(10), 1496-1503.

Biehl, JK., \& Russell, B. (2009). Introduction to stem cell therapy. The Journal of cardiovascular nursing, 24(2), 98.

Birbrair, A., \& Frenette, PS. (2016). Niche heterogeneity in the bone marrow. Annals of the New York Academy of Sciences, 1370(1), 82.

Blau, HM., Brazelton, TR., \& Weimann, JM. (2001). The evolving concept of a stem cell: entity or function? Cell, 105(7), 829-841.

Bollini, S., Cheung, KK., Riegler, J., Dong, X., Smart, N., Ghionzoli, M., Loukogeorgakis, SP., Maghsoudlou, P., Dubé, KN., Riley, PR., Lythgoe, MF., \& De Coppi, P. (2011). Amniotic fluid stem cells are cardioprotective following acute myocardial infarction. Stem cells and development, 20(11), 1985-1994.

Brabletz, S., Schmalhofer, O., \& Brabletz, T. (2009). Gastrointestinal stem cells in development and cancer. The Journal of pathology, 217(2), 307-317.

Brittan, M., \& Wright, NA. (2002). Gastrointestinal stem cells. The Journal of Pathology: A Journal of the Pathological Society of Great Britain and Ireland, 197(4), 492-509.

Cao, W., Cao, K., Cao, J., Wang, Y., \& Shi, Y. (2015). Mesenchymal stem cells and adaptive immune responses. Immunology letters, 168(2), 147-153.

Chagastelles, PC., \& Nardi, NB. (2011). Biology of stem cells: an overview. Kidney international supplements, 1(3), 63-67.

Choi, KH., Yoon, JW., Kim, M., Lee, HJ., Jeong, J., Ryu, M., Jo, C., \& Lee, CK. (2021). Muscle stem cell isolation and in vitro culture for meat production: A methodological review. Comprehensive Reviews in Food Science and Food Safety, 20(1), 429-457.

Clarke, DL., Johansson, CB., Wilbertz, J., Veress, B., Nilsson, E., Karlström, H., Lendahl, U., \& Frisen, J. (2000). Generalized potential of adult neural stem cells. Science, 288(5471), 1660-1663.

Clause, KC., Liu, LJ., \& Tobita, K. (2010). Directed stem cell differentiation: the role of physical forces. Cell communication \& adhesion, 17(2), 48-54.

Cotsarelis, G. (2006). Epithelial stem cells: a folliculocentric view. Journal of investigative dermatology, 126(7), 1459-1468.

Cuende, N., Rasko, JE., Koh, MB., Dominici, M., \& Ikonomou, L. (2018). Cell, tissue and gene products with marketing authorization in 2018 worldwide. Cytotherapy, 20(11), 1401-1413.

Çerci, E., \& Erdost, H. (2019). Kök Hücre. Atatürk Üniversitesi Veteriner Bilimleri Dergisi, 14(2), 221-228.

de Miguel, MP., Prieto, I., Moratilla, A., Arias, J., \& Aller, MA. (2019). Mesenchymal stem cells for liver regeneration in liver failure: from experimental models to clinical trials. Stem cells international, 2019. 
DeGeorge, Jr, BR., Rosenberg, M., Eckstein, V., Gao, E., Herzog, N., Katus, HA., Koch, WJ., Frey, N., \& Most, P. (2008). BMP-2 and FGF-2 Synergistically Facilitate Adoption of a Cardiac Phenotype in Somatic Bone Marrow c-kit+/Sca-1+ Stem Cells. Clinical and translational science, 1(2), 116-125.

Devkate, GV., Tate, SS., Bhujbal, AS., Tupe, AP., \& Patil, RN. (2016). Stem cell: A Review. International Journal of Pharmacy and Pharmaceutical Sciences, 8, 295-311.

Didar, TF., \& Tabrizian, M. (2010). Adhesion based detection, sorting and enrichment of cells in microfluidic Lab-on-Chip devices. Lab on a Chip, 10(22), 3043-3053.

Ditadi, A., de Coppi, P., Picone, O., Gautreau, L., Smati, R., Six, E., Bonhomme, D., Ezine, S., Frydman, R., Cavazzana-Calvo, M., \& André-Schmutz, I. (2009). Human and murine amniotic fluid c-Kit+ Lin- cells display hematopoietic activity. Blood, The Journal of the American Society of Hematology, 113(17), 3953-3960.

Dulak, J., Szade, K., Szade, A., Nowak, W., \& Józkowicz, A. (2015). Adult stem cells: hopes and hypes of regenerative medicine. Acta Biochimica Polonica, 62(3), 329-337.

Fitzsimmons, RE., Mazurek, MS., Soos, \& A., Simmons, CA. (2018). Mesenchymal stromal/stem cells in regenerative medicine and tissue engineering. Stem cells international, 8031718.

Freund, C., Davis, RP., Gkatzis, K., Ward-van Oostwaard, D., \& Mummery, CL. (2010). The first reported generation of human induced pluripotent stem cells (iPS cells) and iPS cell-derived cardiomyocytes in the Netherlands. Netherlands Heart Journal, 18(1), 51.

Girlovanu, M., Susman, S., Soritau, O., Rus-Ciuca, D., Melincovici, C., Constantin, AM., \& Mihu, CM. (2015). Stem cells-biological update and cell therapy progress. Clujul medical, 88(3), 265.

Guo, X. L., \& Chen, JS. (2015). Research on induced pluripotent stem cells and the application in ocular tissues. International journal of ophthalmology, $8(4), 818$.

Hosseinirad, H., Rashidi, M., Moghaddam, MM., Tebyanian, H., Nouraei, S., Mirhosseini, SA., Rasouli, M., \& Habibian, S. (2018). Stem cell therapy for lung diseases: From fundamental aspects to clinical applications. Cellular and Molecular Biology, 64(10), 92-101.

Ismail, A., Hughes, MP., Mulhall, HJ., Oreffo, ROC., \& Labeed, FH. (2015). Characterization of human skeletal stem and bone cell populations using dielectrophoresis. Journal of tissue engineering and regenerative medicine, $9(2), 162-168$.

Johnson, V., Webb, T., Norman, A., Coy, J., Kurihara, J., Regan, D., \& Dow, S. (2017). Activated mesenchymal stem cells interact with antibiotics and host innate immune responses to control chronic bacterial infections. Scientific reports, 7(1), 1-18.

Kalra, K., \& Tomar, PC. (2014). Stem cell: basics, classification and applications. American Journal of Phytomedicine and Clinical Therapeutics, 2(7), 919-930.

Kanev, M., \& Muranlı, F. G. (2016). Flow sitometri ve kullanım alanları. Sakarya Üniversitesi Fen Bilimleri Enstitüsü Dergisi, 20(1), 33-38.

Karaboz, İ., Kayar, E., \& Akar, S. (2008). Flow sitometri ve kullanım alanları. Elektronik Mikrobiyoloji Dergisi, 6(2), 1-18.

Kaur, RP., Ludhiadch, A., \& Munshi, A. (2019). SingleCell Genomics: Technology and Applications. In: Barh D, Azevedo V. Editors. Single-Cell Omics. United States Academic Press. pp: 179-197.

Kaya, MM., \& Tutun, H. (2021). Monoclonal Antibodies and Their Uses in Therapy. Turkish Journal of Agriculture-Food Science and Technology, 9(3), 515-530.

Kishino, Y., Fujita, J., Tohyama, S., Okada, M., Tanosaki, S., Someya, S., \& Fukuda, K. (2020). Toward the realization of cardiac regenerative medicine using pluripotent stem cells. Inflammation and regeneration, 40(1), 1-6.

Kolagar, T. A., Farzaneh, M., Nikkar, N., \& Khoshnam, S.E. (2020). Human pluripotent stem cells in neurodegenerative diseases: potentials, advances and limitations. Current stem cell research \& therapy, 15(2), 102-110.

Kountouras, J., Boura, P., \& Lygidakis, NJ. (2001). Liver regeneration after hepatectomy. Hepatogastroenterology, 48(38), 556-562.

Kowalkowski, T., Buszewski, B., Cantado, C., \& Dondi, F. (2006). Field-flow fractionation: theory, techniques, applications and the challenges. Critical reviews in analytical chemistry, 36(2), 129-135.

Köse, O. (2015). Epidermal Kök Hücreler/Epidermal Stem Cells. Turk Dermatoloji Dergisi, 9(1), 23.

Krasnodembskaya, A., Samarani, G., Song, Y., Zhuo, H., Su, X., Lee, J-W., Gupta, N., Petrini, M., \& Matthay, MA. (2012). Human mesenchymal stem cells reduce mortality and bacteremia in gramnegative sepsis in mice in part by enhancing the phagocytic activity of blood monocytes. American Journal of Physiology-Lung Cellular and Molecular Physiology, 302(10), 1003-1013.

Ku, HT. (2008). Pancreatic Progenitor Cells-Recent Studies. Endocrinology, 149(9), 4312-4316.

Kumar, R., Sharma, A., Pattnaik, AK., \& Varadwaj, PK. (2010). Stem cells: An overview with respect to cardiovascular and renal disease. Journal of natural science, biology, and medicine, 1(1), 43.

Le Blanc, K., \& Davies, LC. (2015). Mesenchymal stromal cells and the innate immune response. Immunology letters, 168(2), 140-146.

Linke, A., Müller, P., Nurzynska, D., Casarsa, C., Torella, D., Nascimbene, A., Castaldo, C., Cascapera, S., Böhm, M., Quaini, F., Urbanek, K., Leri, A., Hintze, TH., Kajstura, J., \& Anversa, P. (2005). Stem cells in the dog heart are self-renewing, clonogenic, and multipotent and regenerate infarcted myocardium, improving cardiac function. Proceedings of the national academy of sciences, 102(25), 8966-8971. 
Liras, A., Segovia, C., \& Gabán, AS. (2013). Pluripotent Stem Cells. In: Bhartiya D, Lenka N. Editors. Induced Pluripotent Stem Cells: Therapeutic Applications in Monogenic and Metabolic Diseases, and Regulatory and Bioethical considerations. London, United Kingdom: In Tech Open, pp: 529-554.

Lu, SJ., Lee, RJ., Napoli, C., Oh, S., Kimbrel, EA., \& Feng, Q. (2011). The promise and therapeutic potential of human ES and iPS cells. Stem Cells International, 959275.

Maehr, R., Chen, S., Snitow, M., Ludwig, T., Yagasaki, L., Goland R., Leibel, RL., \& Melton, DA. (2009). Generation of pluripotent stem cells from patients with type 1 diabetes. Proceedings of the National Academy of Sciences, 106(37), 15768-15773.

Mahla, RS. (2016). Stem cells applications in regenerative medicine and disease therapeutics. International journal of cell biology, 6940283 .

Majekodunmi, SO. (2015). A review on centrifugation in the pharmaceutical industry. American Journal of Biomedical Engineering 5(2), 67-78.

Markides, H., Webb, WR., El Haj, AJ., Chippendale, TWE., Coopman, K., Rafiq, Q., \& Hewitt, C. (2019). Isolation of mesenchymal stem cells from bone marrow aspirate. In: Moo-Young M. Editor. Comprehensive Biotechnology. United Kingdom: Elsevier. pp: 115-123.

Messina, A., Luce, E., Hussein, M., \& DubartKupperschmitt, A. (2020). Pluripotent-stem-cellderived hepatic cells: hepatocytes and organoids for liver therapy and regeneration. Cells, 9(2), 420.

Mirzaei, H., Sahebkar, A., Sichani, LS., Moridikia, A., Nazari, S., Sadri Nahand, J., Salehi, H., Stenvang, J., Masoudifar, A., Mirzaei, HR., \& Jaafari, MR. (2018). Therapeutic application of multipotent stem cells. Journal of Cellular Physiology, 233(4), 2815-2823.

Mitalipov, S., \& Wolf, D. (2009). Totipotency, pluripotency and nuclear reprogramming. Engineering of stem cells, 114, 185-199.

Miyahara, Y., Nagaya, N., Kataoka, M., Yanagawa, B., Tanaka, K., Hao, H., Ishino, K., Ishida, H., Shimizu, T., Kangawa, K., Sano, S., Okano, T., Kitamura, S., Mori, H. (2006). Monolayered mesenchymal stem cells repair scarred myocardium after myocardial infarction. Nature medicine, 12(4), 459-465.

Ng, YY., Baert, MR., de Haas, EF., Pike-Overzet, K., \& Staal, FJ. (2009). Isolation of human and mouse hematopoietic stem cells. Methods in molecular biology, 506, 13-21.

Noguchi, H. (2010). Pancreatic stem/progenitor cells for the treatment of diabetes. The review of diabetic studies. The Review of Diabetic Studies, 7(2), $105-111$

Ohuchi, S. (2012). Cell-SELEX technology. BioResearch open access, 1(6), 265-272.

Overturf, K., Al-Dhalimy, M., Ou, C. N., Finegold, M., \& Grompe, M. (1997). Serial transplantation reveals the stem-cell-like regenerative potential of adult mouse hepatocytes. The American journal of pathology, 151(5), 1273.
Oyar, P. (2016). Dental Kök Hücre Kaynakları ve Kemik Doku Rejenerasyonunda Kullanılma Potansiyelleri. Atatürk Üniversitesi Diş Hekimliği Fakültesi Dergisi, 26(15), 96-101.

Park, Y. G., Moon, J. H., \& Kim, J. (2006). A comparative study of magnetic-activated cell sorting, cytotoxicity and preplating for the purification of human myoblasts. Yonsei medical journal, 47(2), 179.

Passier, R., \& Mummery, C. (2003). Origin and use of embryonic and adult stem cells in differentiation and tissue repair. Cardiovascular research, 58(2), 324-335.

Pethig, R., Menachery, A., Pells, S., \& De Sousa, P. (2010). Dielectrophoresis: a review of applications for stem cell research. Journal of Biomedicine and Biotechnology, 182581

Pirvulet, V. (2015). Gastrointestinal stem cell up-to-date. Journal of medicine and life, 8(2), 245.

Pittenger, M. F., Discher, D. E., Péault, B. M., Phinney, D. G., Hare, J. M., \& Caplan, A. I. (2019). Mesenchymal stem cell perspective: cell biology to clinical progress. NPJ Regenerative medicine, 4(1), 1-15.

Preffer, F., \& Dombkowski, D. (2009). Advances in complex multiparameter flow cytometry technology: Applications in stem cell research. Cytometry Part B: Clinical Cytometry: The Journal of the International Society for Analytical Cytology, 76(5), 295-314.

Radisic, M., Iyer, R. K., \& Murthy, S. K. (2006). Microand nanotechnology in cell separation. International journal of nanomedicine, 1(1), 3.

Rajabzadeh, N., Fathi, E., \& Farahzadi, R. (2019). Stem cell-based regenerative medicine. Stem cell investigation, 6.19.

Rajpoot, S., \& Tewari, G. (2018). Review Article Review on Stem Cells: Basics Classification and Applications. International Journal of Pharmaceutical Sciences Review and Research, 49(2), 48-52.

Kalra, K., \& Tomar, P. C. (2014). Stem cell: basics, classification and applications. American Journal of Phytomedicine and Clinical Therapeutics, 2(7), 919-930.

Ramalho-Santos, M., \& Willenbring, H. (2007). On the origin of the term "stem cell". Cell stem cell, 1(1), 35-38.

Reiss, K., Cheng, W., Ferber, A., Kajstura, J., Li, P., Li, B., Olivetti, G., Homcy, CJ., Baserga, R., \& Anversa, P. (1996). Overexpression of insulin-like growth factor-1 in the heart is coupled with myocyte proliferation in transgenic mice. Proceedings of the National Academy of Sciences, 93(16), 8630-8635.

Reschigliani, P., Zattonii, A., Rodai, B., Michelinii, E., \& Rodai, A. (2005). Field-flow fractionation and biotechnology. TRENDS in Biotechnology, 23(9), 475-483.

Robintoni DA., \& Daley, GQ. (2012). The promise of induced pluripotent stem cells in research and therapy. Nature, 481(7381), 295-305. 
Roda, B., Lanzoni, G., Alviano, F., Zattoni, A., Costa, R., Di Carlo, A., Marchionni, C., Franchina, M., Ricci, F., Luigi Tazzari, P., Pagliaro, P., Scalinci, SZ., Bonsi, L., Reschiglian, P., \& Bagnara, GP. (2009a). A novel stem cell tag-less sorting method. Stem cell reviews and reports, 5(4), 420-427.

Roda, B., Zattoni, A., Reschiglian, P., Moon, M. H., Mirasoli, M., Michelini, E., \& Roda, A. (2009b). Field-flow fractionation in bioanalysis: A review of recent trends. Analytica chimica acta, 635(2), 132-143.

Semedo, P., Burgos-Silva, M., Donizetti-Oliveira, C., \& Camara, NOS. (2011). How do mesenchymal stem cells repair? In: Gholamrezanezhad A. Editors Stem Cells in Clinic and Research. London: United Kingdom, IntechOpen. P:83-104.

Shen, Q., Jin, H., \& Wang, X. (2013). Epidermal stem cells and their epigenetic regulation. International journal of molecular sciences, 14(9), 1786117880.

Singh, V. K., Saini, A., Kalsan, M., Kumar, N., \& Chandra, R. (2016). Describing the stem cell potency: the various methods of functional assessment and in silico diagnostics. Frontiers in cell and developmental biology, 4, 134.

Sobhani, A., Khanlarkhani, N., Baazm, M., Mohammadzadeh, F., Najafi, A., Mehdinejadiani, S., \& Aval, FS. (2017). Multipotent stem cell and current application. Acta Medica Iranica, 6-23.

Soejitno, A., \& Prayudi, PKA. (2011). The prospect of induced pluripotent stem cells for diabetes mellitus treatment. Therapeutic advances in endocrinology and metabolism, 2(5), 197-210.

Song, LIN., \& Tuan, RS. (2004). Transdifferentiation potential of human mesenchymal stem cells derived from bone marrow. The FASEB Journal, 18(9), 980-982.

Stoltenburg, R., Reinemann, C., \& Strehlitz, B. (2007). SELEX - a (r) evolutionary method to generate high-affinity nucleic acid ligands. Biomolecular engineering, 24(4), 381-403.

Tabar, V., \& Studer, L. (2014). Pluripotent stem cells in regenerative medicine: challenges and recent progress. Nature Reviews Genetics, 15(2), 82-92.

Takahashi, K., Tanabe, K., Ohnuki, M., Narita, M., Ichisaka, T., Tomoda, K., \& Yamanaka, S. (2007). Induction of pluripotent stem cells from adult human fibroblasts by defined factors. cell, 131(5), 861-872.

Tateishi, K., He, J., Taranova, O., Liang, G., D'Alessio, AC., \& Zhang, Y. (2008). Generation of insulinsecreting islet-like clusters from human skin fibroblasts. Journal of Biological Chemistry, 283(46), 31601-31607.

Taupin, P., Ray, J., Fischer, WH., Suhr, ST., Hakansson, K., Grubb, A., \& Gage, FH. (2000). FGF-2responsive neural stem cell proliferation requires $\mathrm{CCg}$, a novel autocrine/paracrine cofactor. Neuron, 28(2), 385-397.

Till, JE., \& McCulloch, EA. (1961). A direct measurement of the radiation sensitivity of normal mouse bone marrow cells. Radiation research, 14(2), 213-222.
Ullah, I., Subbarao, RB., \& Rho, GJ. (2015). Human mesenchymal stem cells-current trends and future prospective. Bioscience reports, 35(2)

van Noort, D., Ong, S. M., Zhang, C., Zhang, S., Arooz, T., \& Yu, H. (2009). Stem cells in microfluidics. Biotechnology progress, 25(1), 52-60.

Verhulst, S., Best, J., van Grunsven, L. A., \& Dollé, L. (2015). Advances in hepatic stem/progenitor cell biology. EXCLI journal, 14, 33.

Wei, J.P., Zhang, T.S., Kawa, S., Aizawa, T., Ota, M., Akaike, T., Kato, K., Konishi, I., \&Nikaido, T. (2003). Human amnion-isolated cells normalize blood glucose in streptozotocin-induced diabetic mice. Cell transplantation, 12(5), 545-552.

Wu, HW., Lin, CC., \& Lee, GB. (2011). Stem cells in microfluidics. Biomicrofluidics, 5(1), 013401.

Yamanaka, S. (2020). Pluripotent Stem Cell-Based Cell Therapy-Promise and Challenges. Cell stem cell, 27(4), 523-531.

Yang, R., Liu, F., Wang, J., Chen, X., Xie, J., \& Xiong, K. (2019). Epidermal stem cells in wound healing and their clinical applications. Stem cell research \& therapy, 10(1), 1-14.

Yang, X., Meng, Y., Han, Z., Ye, F., Wei, L., \& Zong, C. (2020). Mesenchymal stem cell therapy for liver disease: full of chances and challenges. Cell \& Bioscience, 10(1), 1-18.

Ye, L., Swingen, C., \& Zhang, J. (2013). Induced pluripotent stem cells and their potential for basic and clinical sciences. Current Cardiology Reviews, 9(1), 63-72.

Zakrzewski, W., Dobrzyński, M., Szymonowicz, M., \& Rybak, Z. (2019). Stem cells: past, present, and future. Stem cell research \& therapy, 10(1), 1-22.

Zappia, E., Casazza, S., Pedemonte, E., Benvenuto, F., Bonanni, I., Gerdoni, E., Giunti, D., Ceravolo, A., Cazzanti, F., Frassoni, F., Mancardi, \& G., Uccelli, A. (2005). Mesenchymal stem cells ameliorate experimental autoimmune encephalomyelitis inducing T-cell anergy. Blood, 106(5), 1755-61.

Zeb Q, Wang C, Shafiq S, Liu L (2019). An Overview of Single-Cell Isolation Techniques. In: Barh D, Azevedo V. Editors, Single-Cell Omics. United States Academic Press pp:101-135.

Zhang, J., Liu, J., Liu, L., McKeehan, WL., \& Wang, F. (2012). The fibroblast growth factor signaling axis controls cardiac stem cell differentiation through regulating autophagy. Autophagy, 8(4), 690-691.

Zhang, J., Wei, X., Zeng, R., Xu, F., \& Li, X. (2017). Stem cell culture and differentiation in microfluidic devices toward organ-on-a-chip. Future Sciencie OA, 3(2), FSO187.

Zhang, Y., Bai, XF., \& Huang, CX. (2003). Hepatic stem cells: existence and origin. World Journal of Gastroenterology: WJG, 9(2), 201

Zhao, X., \& Moore, DL. (2018). Neural stem cells: developmental mechanisms and disease modeling. Cell and tissue research. 371(1),1-6.

Zhu, B., \& Murthy, SK. (2013). Stem cell separation technologies. Current opinion in chemical engineering, 2(1), 3-7. 